\title{
Athanasios af Alexandrias 39. Påskebrev fra påsken 367
}

\author{
Introduktion og oversættelse til dansk
}

\author{
Lektor, dr.theol. \\ Nils Arne Pedersen, Aarhus Universitet og
}

\author{
Ph.d.-stipendiat, cand.mag. \\ Lasse Løvlund Toft, Aarhus Universitet
}

\begin{abstract}
This is the first translation into Danish of the Coptic Sahidic version of Athanasius' famous 39th Festal Letter from AD 367, which established the Biblical Canon and contained for the first time precisely those $27 \mathrm{New}$ Testament scriptures which are still the Christian norm today. The translation is introduced, annotated, and based on the two existing Coptic manuscripts. The Greek excerpt of a part of the Festal Letter is also translated.
\end{abstract}

Keywords: Athanasius - Festal Letters - Biblical Canon - Apocrypha Sahidic - Coptic

\section{Den kirkehistoriske betydning af Athanasios' 39. Påskebrev}

Det er næppe en overdrivelse at sige, at næst efter kejser Konstantin den Store var Athanasios, Alexandrias biskop fra 328 til 373, den person, der fik størst betydning for kristendommens historie i det 4 . århundrede. Dette århundrede var ikke blot den afgørende periode, hvor kristendommen kom til magten og hurtigt gennemtrængte hele Romerrigets samfund og kultur, det var også en periode præget af dybe konflikter om kirkens tro og magten i kirken, hvor Athanasios netop spillede en hovedrolle. ${ }^{1}$ Det er vigtigt at forstå, at disse to for-

1. Litteraturen om Athanasios er enorm; vedrørende hans kirkehistoriske rolle se $\mathrm{fx}$ Duane Wade-Hampton Arnold, The Early Episcopal Career of Athanasius of Alexandria. Christianity and Judaism in Antiquity 6 (Notre Dame/London: Notre Dame University Press 1991); Timothy D. Barnes, Athanasius and Constantius. Theology and Politics in the Constantinian Empire (Cambridge, Mass./London: Harvard University Press 2001); David Brakke, Athanasius and the Politics of Asceticism (Oxford: Oxford University Press 1995); Annick Martin, Athanase d'Alexandrie et l'Église 
hold ikke var modsatrettede tendenser, men at den første tværtimod betingede den anden - den officielle rolle, som kirken nu kom til at indtage, gjorde det nødvendigt at melde klart ud, hvor man stod, hvilket forklarer den søgen efter en mere entydig teologi, som var indeholdt i den såkaldte "arianske strid". I denne strid brugte alle de kirkelige partier Bibelen som grundlag for hele argumentationen, og bl.a. derfor må vi regne med et pres for, at Bibelens omfang også blev entydiggjort, men overhovedet har det været et problem i forhold til den nye stilling, som kirken indtog i det 4. århundrede, at det ikke var klart, hvad der hørte til de hellige skrifter, og hvad der ikke gjorde; nogle kredse fortsatte med at bruge tekster, som andre grupper tog afstand fra som "apokryfe" eller i det mindste ikke ville tildele samme status som de hellige skrifter. Sådan kan man måske forklare den stigende interesse for at opstille afgrænsede lister over omfanget af hellige skrifter, og også her ydede Athanasios et afgørende bidrag med sit berømte 39. Påskebrev til påsken $367 .{ }^{2}$

Brevet er blevet berømt, fordi det for første gang rummer en liste, der omfatter præcis de 27 skrifter, der i dag udgør Det Nye Testamente. Enten man antager, at Athanasios bragte det første skriftlige udtryk for en konsensus, der på denne tid var ved at danne sig i kirkelige kredse, eller man mener, at det direkte var Athanasios, der var årsag til, at Det Nye Testamente fik sit nuværende omfang, er der

d'Égypte au IVE siècle (328-373), Collection de l'École Française de Rome 216 (Rom: École Française de Rome, Palais Farnèse 1996). På dansk kan der også henvises til den korte fremstilling i Nils Arne Pedersen, "Oldkirken", Per Ingesman \& Nils Arne Pedersen, Kirkens historie 1 (København: Hans Reitzels Forlag 2012), 104, 218-227, 256, 260.

2. Allerede i det 3. årh. (jf. Euseb af Caesareas Kirkens Historie VII,20-23, måske endog tidligere) var biskopperne af Alexandria begyndt at skrive opbyggelige påskebreve til de egyptiske menigheder, formodentlig også for at påvirke og dominere dem, men Athanasios' breve er de tidligste, der er bevarede. De indeholder datoer for den kommende faste og påske. Der er også bevaret påskebreve fra de senere alexandrinske biskopper; se vedrørende påskebrevene som sådan Pauline Allen, "The Festal Letters of the Patriarchs of Alexandria: Evidence for Social History in the Fourth and Fifth Centuries", Phronema 29 (2014), 1-19; Andreas Külzer, "Die 'Festbriefe' (غ̇ zantinischen Briefliteratur", ByZ 91 (1998), 379-390. - Om brevenes sammenhæng med den oldkirkelige påskefest se L.W. Barnard, "Some Liturgical Elements in Athanasius' Festal Epistles", TU 116 (= StPatr XIII) (1976), 337-342; Pius Merendino, Paschale Sacramentum. Eine Untersuchung über die Osterkatechese des hl. Athanasius von Alexandrien in ihrer Beziehung zu den frühchristlichen exegetisch-theologischen Überlieferungen, LWQF 42 (Münster: Aschendorffsche Verlagsbuchhandlung 1964). 
tale om en af kirkehistoriens centrale tekster. ${ }^{3}$ Den forelægges her for første gang i dansk oversættelse. ${ }^{4}$

3. Med sin liste kan Athanasios således hævdes at afslutte den proces, der i forskningen er kendt som "den nytestamentlige kanondannelse". Før Athanasios finder vi forskellige kortere "kanonlister"; traditionelt dateres Muratoris Kanon til c. 200 og betragtes dermed som den ældste, se fx diskussionen i Geert Hallbäck, "Muratoris Kanon", Kanon. Bibelens tilblivelse og normative status. Festskrift til Mogens Müller, Forum for Bibelsk Eksegese 15, red. Troels Engberg-Pedersen m.fl. (København: Museum Tusculanums Forlag 2006), 143-167. For nylig er der dog blevet argumenteret for, at Muratoris Kanon er fra det 4 . århundrede, men er skrevet, for at man skulle tro, at den var ældre, se Clare K. Rothschild, "The Muratorian Canon as Roman Fake", NT 60 (2018), 55-82. Hvis det er rigtigt, bliver det mest sandsynligt, at lister først dukker op i det 4. århundrede, således at den ældste nytestamentlige kanonliste er den, der foreligger i Euseb af Caesareas Kirkens Historie III, 25,1-7. Se om denne Everett R. Kalin, "The New Testament Canon of Eusebius", The Canon Debate, red. Lee Martin McDonald \& James E. Sanders (Peabody, Mass. 2002), 386-404. Mens den ældre forskning ( $\mathrm{fx}$ Theodor Zahn, Adolf von Harnack eller Hans von Campenhausen) talte om en kanon, enten når nytestamentlige tekster i begyndelsen af det 2 . århundrede blev behandlet på linje med Det Gamle Testamente, eller når Markion lidt senere gav stødet til en afgrænsning, ville Albert C. Sundberg og mange, der er inspirerede af ham, blot sige, at der her er tale om, at teksterne er blevet "skrifter", mens betegnelsen "kanon" skal forbeholdes de senere lukkede lister, se Sundberg, "Towards a Revised History of the New Testament Canon", TU 89 (StEv IV) (1968), 452-461. Disse begreber kan tilsløre kanondannelsens karakter af en sammenhængende proces, og derfor vil andre hellere tale om en "åben" og "lukket" kanon, se diskussionen i Harry Y. Gamble, "The New Testament Canon: Recent Research and the Status Quaestionis", The Canon Debate, red. McDonald \& Sanders, 267-294. Det er dog vigtigt at være opmærksom på, at der i alle tilfælde er tale om moderne begreber, der er dannet med henblik på at analysere den fortidige udvikling, og ikke begreber, der allerede blev brugt på denne entydige måde af forfatterne i oldtiden. Bemærk også, at

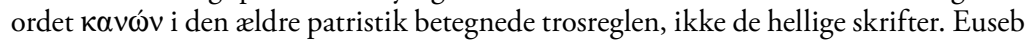
brugte det ikke om sin egen liste i Kirkehistorien; i III,25,6 kaldte han sin fortegnelse

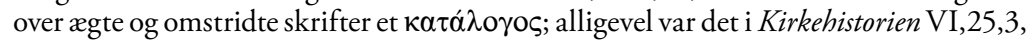

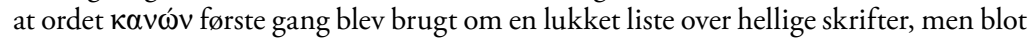
til at karakterisere Origenes' accept af de fire evangelier. Athanasios var netop den første forfatter, der var tæt på at foregribe den moderne begrebsdannelse, idet han c. år 350 brugte navneordet Kavஸ́v om hele Det Nye Testamente (De Decretis 18,3) og

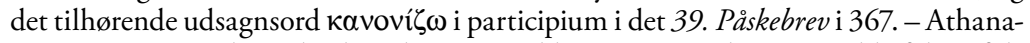
sios giver i øvrigt det indtryk, at han også vil kanonisere en bestemt rækkefølge af de hellige skrifter fra Genesis til Johannes' Åbenbaring, hvilket, som i sin tid foreslået af Theodor Zahn, "Athanasius und der Bibelkanon", Festschrift der Universität Erlangen zur Feier des achtzigsten Geburtstages Sr. königlichen Hoheit des Prinzregenten Luitpold von Bayern (Erlangen og Leipzig: A. Deichert'sche Verlagsbuchhandlung Nachf. 1901), 9-11, kan afspejle eksistensen af enorme Bibelkodexer som Codex Sinaiticus og Codex Alexandrinus, som kirken formodentlig først fik økonomisk mulighed for at fremstille i den konstantinske epoke, hvilket altså i så fald også viser, hvordan Athanasios' ideer er bestemt af den nye tid, som han levede i.

4. I skandinavisk sammenhæng findes der hidtil kun en svensk oversættelse af det græske uddrag af Sten Hidal i: Bibel och predikan, red. S. Hidal, Svenskt Patristiskt Bibliotek IV (Skellefteå: Artos Bokförlag 2003), 67-69. 
Man skal ikke læse langt ind i det 39. Påskebrev, før man forstår, at det afspejler voldsomme konflikter. Her skal Athanasios' historie ikke genfortælles, men det skal kort nævnes, hvilke navngivne grupper der polemiseres imod: Hovedmodstanderen i brevet er melitianerne, en skismatisk gruppe udbredt i hele Egypten. Gruppen havde sin oprindelse $\mathrm{i}$ et krav om en hårdere kurs mod frafaldne i den "Store Forfølgelse" i begyndelsen af århundredet, men var efterhånden blevet samlingssted for modstand mod Alexandria-sædets ledende rolle og Athanasios' person. Athanasios hævder, at melitianerne står bag de udbredte apokryfer, men det er klart af brevet, at disse også bliver læst af hans egne tilhængere, der skal advares imod dem.

Skønt vi ved, at nytestamentlige apokryfer var vidt udbredt i Egypten på denne tid, er de apokryfer, der nævnes i brevet, udelukkende tillagt personer fra Det Gamle Testamente (Enok, Moses og Esajas).

Brevet nævner også arianerne, som var Athanasios' samlebetegnelse for en række kirkelige partier, der alle hævdede en subordinerende kristologi. De bliver ikke direkte forbundet med apokryfer, men de inddrages, fordi de havde en taktisk alliance med melitianerne, der ifølge Athanasios også var ved at udvikle sig til en teologisk overensstemmelse.

Derudover bringer Athanasios en kort liste over andre hæretikere, der afsløres af de bibelske skrifter: Manikaerne benægter skabelsen af intet, og Markion fornægtede loven og kontinuiteten mellem den og Kristus; sandsynligvis nævnes også frygere, dvs. montanisterne, der hævdede, at de fortsat modtog åbenbaringer ved Helligånden gennem deres "nye profeter" - åbenbaringer, der potentielt kunne modsige eller problematisere udsagn fra Skrifterne. Af disse tre grupper var det dog sandsynligvis kun manikæerne, der spillede en rolle $\mathrm{i}$ Egypten på Athanasios’ tid.

\section{Tekstoverleveringen}

Mellem 329 og sit dødsår i 373 udsendte Athanasios en lang række festbreve; hans konfliktfyldte episkopat med lange perioder i eksil betød dog, at det adskillige gange ikke var muligt at udsende et brev. Brevene, der alle var på græsk, blev efter hans død samlet og nummeret. $^{5}$

5. En vigtig større undersøgelse af påskebrevene foreligger i Alberto Camplani, Le lettere festali di Atanasio di Alessandria. Studio storico-critico (Rom: C.I.M., Unione Accademica Nazionale, Corpus dei Manoscritti Copti Letterari 1989). 
Af den græske grundtekst er kun nogle ganske korte citater bevarede i 10. Bog af den byzantinske forfatter Kosmas Indikopleustes' Kristne Topografi fra det 6. århundrede, ${ }^{6}$ samt et længere excerpt netop fra det 39. Påskebrev. Det er let at se, hvad der har været den ledende interesse, da stykket blev excerperet, for af det lange brev omfatter excerptet kun den bibelske kanonliste og den nærmeste omgivende kontekst. Man har altså ønsket at fastholde den store kirkefaders autoritet i forhold til Bibelens omfang, men har formodentlig villet undgå konteksten, der drejede sig om tidsbestemte egyptiske stridigheder, som kunne tilsløre kanonlistens rolle som tidløs kirkeretslig norm. Hvornår stykket blev excerperet, ved vi ikke, men i hvert fald ser det ud til at have indgået i byzantinernes kirkeret som følge af det koncil, der fandt sted i Konstantinopel i 692 og kaldes Anden Trullanum eller Quinisextum. Koncilets 2. canon gjorde en hel række forskellige patristiske tekster til officielt forpligtende skrifter og nævnte i den sammenhæng også kanoniske breve af Athanasios. Hvilke tekster, der mentes, blev ikke præciseret, og det var først i det 12. årh., at Anden Trullanums bestemmelser blev reciperet i hele den byzantinske kirke. ${ }^{7}$ Excerptet er ofte blevet udgivet og to gange i det 20. århundrede. ${ }^{8}$

Med disse undtagelser er brevene gået tabt på deres græske originalsprog, men til gengæld er en stor del af dem bevaret i oversættelser til syrisk og til sahidisk koptisk. Den syriske oversættelse er bevaret i et enkelt håndskrift, British Library Add 14569, der stammer fra det 8. århundrede, og den blev udgivet af William Cureton i 1848. ${ }^{9}$ Håndskriftet er formodentlig et af dem, som Moses af Nisibis i 932 bragte fra Syrien til Syrernes Kloster (Dayr al-Suryān) i Egypten i den Nitriske Ørken. I 1838 købte Archdeacon Henry Tattam dele af håndskriftet, der blev bragt til England, og senere blev andre dele erhvervet for biblioteket af Auguste Pacho i $1847 .{ }^{10}$ Desværre er en

6. Se Wanda Wolska-Conus, Cosmas Indicopleustès Topographie chrétienne III, SC 197 (Paris: Les éditions du cerf 1973), 240-255.

7. Péricles-Pierre Joannou, Fonti. Discipline générale antique, IVee-IXe siècle. II. Les Canons des pères grecs (Rom: Grottaferrata 1963), xiv-xvii.

8. En ældre udgave foreligger i Migne PG 26, 1435-1440. Nyere kritiske udgaver i Joannou (1963), 71-76 (med fransk oversættelse) og i Stergios N. Sakkos, "'H $\Lambda \Theta '$

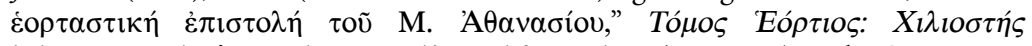

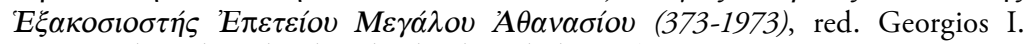
Mantzarides (Thessaloniki: Theologikê Scholê 1974), 171-182.

9. William Cureton, The Festal Letters of Athanasius, Discovered in an Ancient Syriac Version (London: Printed for the Society for the Publication of Oriental Texts 1848).

10. Se redegørelserne i Cureton (1848), i-xv, xxiv; William Wright, Catalogue of the Syriac manuscripts in the British Museum acquired since the year 1838, III (London: Printed by Orders of the Trustees 1872), xi-xv; endvidere Sebastian Brock, "Without 
stor del af håndskriftet gået tabt, således at det 39. Påskebrev ikke er bevaret. Den syriske oversættelse indledes dog med et Index, som også er oversat fra græsk, og som opstiller en kronologi og historisk kontekst for hvert af festbrevene, herunder det 39. Paiskebrev. ${ }^{11}$

Ikke desto mindre er et excerpt af 39. Påskebrev bevaret i syrisk oversættelse i et andet håndskrift, British Library Add 12168; det blev også udgivet af Cureton. Også dette excerpt omfatter netop den bibelske kanonliste, men da det ikke fuldstændig svarer til det græske excerpt i omfang, er det formodentlig, som hævdet af Zahn, et selvstændigt udtog med egen tekstkritisk værdi. ${ }^{12}$

Imidlertid er størstedelen af brevet bevaret i en sahidisk oversættelse, der stammer fra det såkaldte Hvide Kloster i Øvreegypten. Dette kloster, der er kendt for sin abbed Shenoute (347-465), en meget vigtig koptisk forfatter, besad oprindeligt et vældigt bibliotek, men i moderne tid blev kodeksernes læg og blade taget fra hinanden og spredt til museer og biblioteker i hele verden. Det var den tyske koptolog Carl Schmidt (1868-1938), der først identificerede og udgav blade som hørende til Athanasios' 39. Paskebrev. ${ }^{13}$ Senere er mange flere blade fra hans påskebreve blevet identificeret, som viser sig at stamme fra tre håndskrifter, der alle er defekte; de betegnes MONB.AR, MONB.AS og MONB.AT. Det er dog kun MONB.AS og MONB. AT, der rummer dele af det 39. Paskebrev, men sammenlagt har de så også bevaret næsten hele det 39. Påskebrev, når vi ser bort fra en stor lakune i begyndelsen og en anden nær slutningen. I $1955 \mathrm{blev}$ alt, hvad der indtil da var blevet identificeret af påskebrevene, udgivet af Louis Théophile Lefort; fra det 39. Påskebrev drejer det sig om fem blade i Bibliothèque nationale i Paris og to blade $\mathrm{i}$ the Bodleian Library i Oxford, der hører til håndskriftet AS, samt ét blad mere fra Paris og ét fra Österreichische Nationalbibliothek i Wien, der hører til håndskriftet AT. ${ }^{14}$ Der blev imidlertid ved med at dukke nye sahidiske blade op, der hørte til påskebrevene, ${ }^{15}$ heriblandt 6 blade fra det 39. Påskebrev, der tilhører Institut Français d'Archéologie Orientale

Mushē of Nisibis, where would we be? Some Reflections on the Transmission of Syriac Literature," Journal of Eastern Christian Studies 56 (2004), 15-24.

11. Cureton (1848), lx-lxi.

12. Cureton (1848), נוג-נב. Se Zahn (1910), 4.

13. Carl Schmidt, "Der Osterfestbrief des Athanasius vom J. 367", NGWG.PH 1898, 167-203, idem, "Ein neues Fragment des Osterfestbriefes des Athanasius vom Jahre 367", NGWG.PH 1901 (1902), 326-349.

14. Louis Théophile Lefort, S. Athanase Lettres festales et pastorales en copte, CSCO.C 150,19 (Louvain: Imprimerie orientaliste L. Durbecq 1955).

15. René-Georges Coquin \& Enzo Lucchesi, "Un complément au corpus copte des Lettres festales d'Athanase (Paris, B.N., Copte 176*) (Pl. III)", OLoP 13 (1982), 137142. 
i Cairo og også hører til håndskriftet AT. ${ }^{16}$ I 1994 udgav Alla Elanskaya yderligere et enkelt blad, der tilhører A.S. Pushkin State Fine Arts Museum i Moskva; senere påviste Enzo Lucchesi, at det også hører til AT og er en del af det 39. Påskebrev. ${ }^{17}$

Ud over disse primærkilder findes der 3 korte citater af påskebrevet i senere litteratur, som foruden at have en vis tekstkritisk værdi er interessante kilder til brevets receptionshistorie. Det første findes i den føromtalte abbed Shenoutes sahidiske værk Contra Origenistas $(\$ 319),{ }^{18}$ hvor han bringer et kort citat fra det 39. Påskebrev kap. 32. Et citat fra brevets kap. 16 findes først i den sahidiske ${ }^{19}$ og senere i den bohairiske ${ }^{20}$ udgave af Pakhoms Liv. På syrisk findes der i et brev fra Jakob af Edessa (630-708) til stylitten Johannes af Litarba et kort citat fra det 39. Påskebrevs kap. 21. Jakob bringer citatet som led i sin fremlæggelse af argumenter for ægtheden af Enoks bog, hvor Jakob forklarer, at kirkens store lærer Athanasios i sin trods alt menneskelige fejlbarlighed ikke havde gennemtænkt sin holdning til Enoks bog, og at han blot henkastet havde ytret det negative udsagn. ${ }^{21}$

Sluttelig skal det nævnes, at der også findes flere moderne oversættelser af den sahidiske tekst, der alle kan bidrage til fortolkningen af den. ${ }^{22}$

16. Coquin, "Les Lettres festales d'Athanase (CPG 2102). Un nouveau complément: Le manuscript IFAO, Copte 25 (Planche X)", OLoP 15 (1984), 133-158.

17. Alla L. Elanskaya, The Literary Coptic Manuscripts in the A.S. Pushkin State Fine Arts Museum in Moscow. Supplements to VigChr XVIII (Leiden, New York og Köln: Brill 1994), 379-381; Enzo Lucchesi, "Un nouveau complément aux Lettres festales d'Athanase", AnBoll 119 (2001), 255-260. Se også den nye udgave af dette blad i David Brakke, "A New Fragment of Athanasius's Thirty-Ninth Festal Letter: Heresy, Apocrypha, and the Canon", HThR 103 (2010), 62-64.

18. Hans-Joachim Cristea, Schenute von Atripe: Contra Origenistas, Studien und Texte zu Antike Christentum 60 (Tübingen: Mohr Siebeck 2011), 70-75 og 144145.

19. Louis Théophile Lefort, S. Pachomii Vitae. Sahidice Scriptae, CSCO.C 99,8 (Paris 1933), 283. Citatet i fragment 7 synes at være blevet overset i den efterfølgende forskning, for det mangler i gennemgangen af alle koptiske citater fra Athanasios' påskebreve i Camplani (1989), 49-50, hvor kun citatet i den bohairiske udgave af Pakhoms Liv (se næste note) anføres.

20. Louis Théophile Lefort, S. Pachomii Vita. Bohairice Scripta, CSCO.C 89,7 (Paris 1925$), 176$.

21. Den syriske tekst findes i William Wright, "Two epistles of Mār Jacob, bishop of Edessa”, JSL 4. Ser. 10 (1867), $430.433+\sim$ - دـ. Den relevante passage findes på side - - †. En fransk oversættelse kan tilgås i François Nau, "Traduction des lettres XII et XIII de Jacques d'Édesse", ROC, dixième année (1905), 206-208.

22. Jf. Schmidt (1898); idem (1902); Lefort, S. Athanase Lettres festales et pastorales en copte, traduites CSCO.C 151.20 (Louvain: Imprimerie orientaliste L. Durbecq 1955a); Pius Merendino, Osterfestbriefe des Apa Athanasios. Aus dem Koptischen übersetzt und erläutert (Düsseldorf: Patmos-Verlag 1965); Coquin (1984); Camplani, Atanasio di Alessandria Lettere festali. Anonimo Indice delle Lettere festali. Introdu- 
Det 39. Paskebrev myldrer med citater fra og hentydninger til Bibelen. Nogle citater er direkte angivet med indledningsformler som "han skriver" eller "han sagde" o.l. Meget ordrette gengivelser af bibelteksten betragter vi imidlertid også som citater, selv om der ikke er anvendt citationsformler. Disse to typer af citater skelner vi fra de løsere hentydninger, der spiller på bibelord.

Enkelte stikprøver af citaterne tyder på, at den sahidiske oversætter $i$ sit arbejde har inddraget den foreliggende sahidiske version af Bibelen; nogle af disse er anført i noterne til denne oversættelse. En gennemført sammenligning af alle citater med denne version er en vigtig, fremtidig opgave, der formodentlig også i mange tilfælde vil kunne bidrage til en mere korrekt tekst. ${ }^{23}$ Stikprøverne viser nærhed, men ikke fuld overensstemmelse med teksterne i udgaverne af den sahidiske version; dette skyldes den normale variation i håndskriftmæssig overlevering af tekster, men måske tillige at oversætteren både har oversat citaterne fra Athanasios' tekst og støttet sig til den eksisterende sahidiske version.

\section{Bemærkninger til nærværende oversættelse}

Hvad der ikke findes, er derimod en samlet og kritisk udgave af den sahidiske tekst: AS og AT er udgivet hver for sig og successivt, efterhånden som bladene blev identificeret. Hvor der allerede fandtes en udgivet tekst fra AS, nøjedes Coquin oven i købet med at bringe en

zione, traduzione e note, Letture cristiane del primo millennio 34 (Milano: Paoline Editoriale Libri 2003); Gabriella Aragione, "La Lettre Festale 39 d'Athanase. Présentation et traduction de la version copte et de l'extrait grec", Le canon du Nouveau Testament. Regards nouveaux sur l'histoire de sa formation, red. G. Aragione, E. Junod og E. Norelli, Le monde de la Bible 54 (Genève: Labor et fides 2005), 197-219; Brakke (2010).

23. Et eksempel foreligger nedenfor i note 171. Der findes ikke en samlet udgave af den sahidiske Bibel; i mangel af bedre har vi benyttet George William Horners udgave af Det Nye Testamente, The Coptic Version of the New Testament in the Southern Dialect otherwise called Sahidic and Thebaic I-VII (Oxford: Oxford University Press 1911-1924), hvis kvalitet ikke er så høj, men også det meget gamle håndskrift fra det 5. årh. med Markus-, Lukas- og Johannesevangelierne ved Hans Quecke: Das Markusevangelium sä̈disch. Text der Handschrift PPalau Rib. Inv.-Nr. 182 mit den Varianten der Handschrift M 569, PapyCast 4 (Barcelona 1972); Das Lukasevangelium saïdisch. Text der Handschrift PPalau Rib. Inv.-Nr. 181 mit den Varianten der Handschrift M 569, PapyCast 6 (Barcelona 1977); Das Johannesevangelium saïdisch. Text der Handschrift PPalau Rib. Inv.-Nr. 183 mit den Varianten der Handschriften 813 und 814 der Chester Beatty Library und der Handschrift M 569, PapyCast 11 (Rom \& Barcelona 1984). 
liste over AT’s varierende læsemåder. En sammenligning med fotografier af bladene fra AS og AT viser desuden, at Leforts og Coquins udgaver er meget ufuldstændige: Hele ord er glemt, og der er et mylder af småfejl, især hvad angår koptiske tegn som supralineare streger o.l. Der er ikke noget af dette, der rokker ved den samlede forståelse af teksten, men det understreger, at der stadig står meget filologisk arbejde tilbage i forhold til denne vigtige tekst.

Nærværende oversættelse af den sahidiske tekst er baseret på udgaverne hos Lefort (1955), Coquin (1984), Elanskaya (1994) og Brakke (2010), samt fotografier af alle de relevante blade fra håndskrifterne AS og AT. Da der ikke findes en kritisk tekst, har vi valgt også at oversætte alle de varierende læsemåder, som vi ikke har taget med i brødteksten, og bringe dem i fodnoterne. Den græske tekst er oversat fra udgaven i Joannou (1963). Generelt ligger den syriske tekst tæt på den græske; vi bringer ikke en oversættelse, men nøjes med at anføre interessante varianter i noterne. I øvrigt bygger vi her på Cureton (1848) og et fotografi af håndskriftet.

Den sahidiske tekst var emnet ved det årlige Nordic Coptic Network Meeting, der fandt sted i Aarhus den 12.-15. august 2019; nærværende oversættelse har nydt godt af diskussionerne ved den lejlighed.

Begyndelsen af brevet er gået tabt, men da der er numre ved de bevarede læg, er det muligt at sige, hvor meget der mangler, og Camplani, der har inddelt brevet i kapitler, har skønnet, at der omtrent mangler, hvad der svarer til fem kapitler. Der er også en større lakune i den sidste del af brevet, som Camplani har ladet svare til to forsvundne kapitler.

I de første fem kapitler er det muligt, at Athanasios først har skildret menneskets skabelse og syndefald for derudfra at fortsætte med inkarnationen. ${ }^{24}$ Det er i hvert fald dér, den bevarede tekst sætter ind, og temaet er den inkarnerede som alles larer.

\section{Indholdsoversigt}

Eftersom vi har valgt at bringe en oversættelse med tekstkritiske kommentarer i fodnoter, har vi holdt os forholdsvis tæt op ad den koptiske tekst. At oversætte er dog altid et kompromis mellem det

24. Jf. at Allen (2014), 6-7, der giver en formkritisk oversigt over de alexandrinske påskebreve som genre, fremhæver, at påskebrevene begynder med at beskrive menneskehedens situation efter faldet og fortsætter med inkarnationen som åbenbaring af Gud og frelseshandling. Dette er også grundlæggende i Athanasios' teologi. 
ordrette og det mundrette, og vi håber, at resultatet er en tekstnær oversættelse, som stadig lyder som idiomatisk dansk. Det til trods bliver teksten nogle steder knudret og Athanasios' lange ytringer med adskillige bisætninger skal ofte læses en ekstra gang. For at lette læsningen og give et indtryk af brevets indhold, bringer vi en indholdsoversigt samt anførsel af de skriftsteder, som Athanasios citerer eller tydeligt alluderer til:

\begin{tabular}{|c|c|c|}
\hline Kapitel & Indhold & $\begin{array}{l}\text { Henvis- } \\
\text { ninger til } \\
\text { skriftsteder }\end{array}$ \\
\hline $\begin{array}{l}\text { Kap. } \\
1-5\end{array}$ & Ikke bevaret. & - \\
\hline $\begin{array}{l}\text { Kap. } \\
6-12\end{array}$ & $\begin{array}{l}\text { Fragmentarisk. Gudfrygtighedens lære } \\
\text { og Jesus som alles lærer. Læren går fra } \\
\text { Jesus gennem apostlene, særligt Paulus, } \\
\text { til de tidlige menigheder, som gennem } \\
\text { skrifterne også omfatter Athanasios' } \\
\text { samtid. Jesus er den eneste kilde til den- } \\
\text { ne frelsens lære og er derfor den eneste, } \\
\text { som reelt kan kaldes "lærer". Tvetydig- } \\
\text { hed i skrifterne kan dog ikke forbigås } \\
\text { uden forklaring: De "lærere", som om- } \\
\text { tales i skrifterne, er ikke selv ophav til } \\
\text { den lære, de forkynder. De er primært } \\
\text { disciple og altså kun i udvidet sekundær } \\
\text { forstand "lærere". }\end{array}$ & $\begin{array}{l}\text { Gal 1,11-12; } \\
\text { Ef 1,17; } \\
\text { Ef 3,2-5; } \\
\text { Luk 19,47; } \\
\text { Luk 22,9; } \\
22,10-11 ; \\
1 \text { Kor 2,9; } \\
\text { Matt 23,8-11; } \\
1 \text { Tim 2,7; } \\
\text { Ef 4,11; } \\
\text { Jak 3,1; } \\
\text { Matt } 10,27 ; \\
1 \text { Kor } 12,28\end{array}$ \\
\hline $\begin{array}{l}\text { Kap. } \\
13-14\end{array}$ & $\begin{array}{l}\text { Jødernes afvisning af den sande lære. } \\
\text { Arianerne og melitianernes afvigelse fra } \\
\text { læren. Pontius Pilatus er et billede på jø- } \\
\text { derne og Herodes et billede på arianerne } \\
\text { og melitianerne. }\end{array}$ & $\begin{array}{l}\text { Joh } 7,15 ; \\
\text { Es } 1,6 ; \\
\text { Sl } 81,5 ; \\
\text { Sl 2,1; } \\
\text { Joh } 18,38 ; \\
\text { Luk } 23,18.21 ; \\
\text { Ex } 14,25\end{array}$ \\
\hline
\end{tabular}




\begin{tabular}{|c|c|}
\hline Kapitel & Indhold \\
\hline $\begin{array}{l}\text { Kap. } \\
15-19\end{array}$ & $\begin{array}{l}\text { De hellige skrifter som den tilstrækkeli- } \\
\text { ge kilde til den sande lære. I forbindel- } \\
\text { se med årets påskefejring vil Athanasios } \\
\text { opstille en liste over de overleverede og } \\
\text { kanoniserede bøger, idet han frygter, } \\
\text { at enkle mennesker vil blive vildledt af } \\
\text { hæretikernes apokryfe bøger, som nogle } \\
\text { har skrevet som påfund og blandet med } \\
\text { de ægte hellige skrifter. Han påskynder } \\
\text { sin flok til at undersøge, om deres bøger } \\
\text { stemmer overens med hans liste. Listen } \\
\text { over Det Gamle og Det Nye Testamentes } \\
\text { bøger er ifølge Athanasios en lukket liste, } \\
\text { og disse bøger, hverken flere eller færre, } \\
\text { er kilderne til frelsen. }\end{array}$ \\
\hline
\end{tabular}

Kap. Skrifter til læsning for katekumenerne.

20 Der findes dog bøger, som ikke er blevet kanoniseret, men som ikke desto mindre er overleveret fra fædrene som bøger, der kan læses af katekumener, som ønsker at lære om fromhedens ord.

Kap. Apokryfe bøger. Hæretikernes apokry-

21-23 fe bøger er opdigtede fabler, som skaber splid i kirken og tilskynder til krig mellem mennesker. Gammeltestamentelige patriarker som Enok, Esajas og Moses kan umuligt have skrevet apokryfe bøger ifølge vidnesbyrdet fra de hellige skrifter. Selv hvis der findes nogle nyttige ord i apokryferne, er de stadig vildledende, da

Henvisninger til skriftsteder

Luk 1,1-4;

Matt 22,29;

Joh 5,39

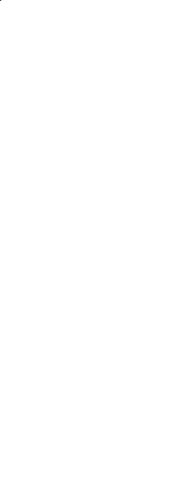
deres forfattere har indført disse få nytteord for at tildække deres onde lærdomme.

Deut 4,2;

Es 40,9;

Es 45,19;

Deut 4,26;

Deut 30,19;

Deut 31,28;

$2 \operatorname{Tim} 4,3-4$;

Jer 8,22 ;

Jer 2,18 
Henvis-

ninger til

Kapitel Indhold

skriftsteder

Kap. $\quad$ Forsvar for ortodokse læresætninger og Joh 1,14;

24-25 angreb på hæretiske. Den hellige Tre- Matt22,31-32;

enighed er mulig at kende gennem skrif- Rom 14,10;

terne. Athanasios bringer et lille katalog 2 Kor 5,10;

over bibelcitater, der giver belæg for dog- Es 40,23;

merne om Jesu menneskelighed, opstan- Es 40,26;

delsen og den kommende dom, sikkert Hebr 11,3;

for at udruste sin flok med overbevisende Rom 7,12;

citater, som kan fremføres i en debat mod Joh 5,46;

tilhængere af en afvigende lære. Athana- Joh 5,39;

sios bringer en kort gendrivelse af en Joh 1,1

række hæresier ved hjælp af skriftcitater.

Kap. Fragmentarisk. Athanasios gendriver en 1 Kor 2,9;

26-27 påstand blandt hæretikerne om, at Pau-

Es 29,18-19;

lus citerer fra en apokryf bog i 1 Kor 2,9. Rom 10,20;

Rom 4,6;

Rom 11,9;

Rom 10,19;

Rom 11,2

Kap. Fragmentarisk. Athanasios giver instruk- -

28-29 tioner om den rette undervisning af katekumener fra skriftens ord.

Kap. Ikke bevaret.

$30-31$

Kap. Fragmentarisk. Opbyggende og opsum- Matt

32 merende ord. Selvom det kan synes sådan, må modtagerne af brevet ikke for25,21.23; 1 veksle Athanasios selv med en lærer, han $\operatorname{Tim} 3,15$ har blot fortalt det videre, som han har fàet overleveret fra sin åndelige fader, Alexander. Athanasios opfordrer til at rense kirken for tvesind og til at være tilfredse med skriften alene. 


\begin{tabular}{lll} 
Kapitel & Indhold & $\begin{array}{l}\text { Henvis- } \\
\text { ninger til } \\
\text { skriftsteder }\end{array}$ \\
\hline $\begin{array}{l}\text { Kap. } \\
33\end{array}$ & $\begin{array}{l}\text { Annoncering af tidspunktet for faste- } \\
\text { tidens begyndelse og for tidpunktet for } \\
\text { påskeugen. Afsluttende hilsener. }\end{array}$ & $\begin{array}{l}2 \text { Ezra 18,10 } \\
=\text { Neh 8,10; } \\
1 \text { Kor 10,31 }\end{array}$ \\
Kap. & $\begin{array}{l}\text { Fragmentarisk. Besked om biskopper, } \\
\text { som er afgået ved døden i løbet af det } \\
\text { forgangne år, og om indsættelsen af deres } \\
\text { efterfølgere. }\end{array}$ & \\
& -
\end{tabular}

\section{Tekstkritiske tegn og andre tegn anvendt i denne oversættelse}

[ ] skarpe parenteser har to anvendelser i brødteksten:

For det første til angivelse af lakuner i håndskrifterne, hvor teksten er helt forsvundet; der skrives [ ], når den forsvundne tekst ikke kan rekonstrueres, og fx [Gud], når der oversættes fra et forslag til rekonstruktion. Skarpe parenteser bruges på tilsvarende måde ved citater fra den koptiske grundtekst i noterne.

For det andet til at anføre de steder i Bibelen, som Athanasios citerer eller hentyder til; der skrives fx [Gal 1,1], hvor der er tale om et citat, eller [jf. Gal 1,1], hvor der sandsynligvis er tale om en hentydning. Når hentydningerne er særligt usikre, anføres de dog i en note og ikke i skarp parentes i brødteksten.

() runde parenteser anvendes i brødteksten for at lette læsningen.

$<>$ kantede parenteser anvendes i brødteksten til at angive oversættelser af emendationer i teksten, hvor der ingen lakune er i håndskriftet, men hvor tekst alligevel ved en fejl ikke er blevet afskrevet eller er blevet afskrevet forkert. Kantede parenteser bruges på tilsvarende måde ved citater fra den koptiske grundtekst i noterne.

(?) angiver, at et rekonstruktionsforslag synes særligt usikkert.

Prikker under koptiske bogstaver i noterne angiver, at læsningen er usikker (fx e).

Prikker ved koptiske ord i noterne angiver bevarede bogstavspor (således $\overline{\mathrm{N}} \mathrm{q} . .$.$) .$

$\dagger$ i noterne angiver en koptisk kvalitativ (stativ) ( $\mathrm{fx}_{\mathrm{x}} \dagger$ †).

(...) angiver forkortelser i citater i noterne. 


\section{Særlige forkortelser anvendt i noterne til denne oversættelse:}

Bibeludgaver:

MT: Den hebraisk-masoretiske tekst af Den Hebraiske Bibel. Udgave: Biblia Hebraica Stuttgartensia, udg. af K. Elliger og W. Rudolph (Stuttgart: Deutsche Bibelstiftung 1967/77).

LXX: Septuaginta, den græske oversættelse af Det Gamle Testamente. Udgave: Septuaginta Id est Vetus Testamentum graece iuxta LXX interpretes, udg. af Alfred Rahlfs, 2 bind (Stuttgart: Württembergische Bibelanstalt 1935).

$\mathrm{NA}^{28}$ : Det græske Nye Testamente. Udgave: Nestle-Aland Novum Testamentum Graece, 28. udg., udg. af Institut für Neutestamentliche Textforschung Münster/Westfalen (Stuttgart: Deutsche Bibelgesellschaft 2012).

Ordbøger:

Bauer: Walter Bauer, Griechisch-Deutsches Wörterbuch zu den Schriften des Neuen Testaments und der übrigen urchristlichen Literatur (Berlin \& New York: De Gruyter 1971).

Crum: Walter Ewing Crum, A Coptic Dictionary. Compiled with the Help of Many Scholars (Oxford: At the Clarendon Press 1939).

Kasser: Rodolphe Kasser, Compléments au Dictionnaire Copte de Crum, PIFAO:BEC VII (Cairo 1964).

Lampe: G.W.H. Lampe, A Patristic Greek Lexicon (Oxford: At the Clarendon Press).

LSJ: A Greek-English Lexicon. Compiled by Henry George Liddell and Robert Scott. Revised and augmented by Henry Stuart Jones. With a Supplement 1968 (Oxford: At the Clarendon Press 1990).

Håndskrifter:

AS: $\quad$ Det koptiske håndskrift MONB.AS. Vidne til den koptiske oversættelse af påskebrevet. Se afsnit II om tekstoverleveringen.

AT: Det koptiske håndskrift MONB.AT. Vidne til den koptiske oversættelse af påskebrevet. Se afsnit II om tekstoverleveringen. 


\section{Oversættelse}

6 [ ] som liv, og han kom til dem, der var døde, og som Gud kom han til menneskene. På denne måde har også ${ }^{25} \mathrm{dem}$, der søger ham, fundet ham, og han blev åbenbaret for dem, der ikke spurgte efter ham. ${ }^{26}$ På denne måde blev han også lys for de blinde, da han åbnede deres øjne, og han blev en stav for de lamme, da han helbredte dem, så de gik [jf. Matt 11,5/Luk 7,22]. Kort sagt: Én gang for alle blev han lærer for enhver i alting.

7 For gudfrygtighedens lære er ikke fra mennesker, men det er Herren, der åbenbarer sin Fader for hvem, han vil, ligesom det er ham, der kender ham [jf. Luk 10,22]. Og apostlene blev de første, for hvem han gjorde dette; en af dem var Paulus, der skriver således til galaterne: "Men, brødre, jeg gør jer bekendt med evangeliet, som det er blevet forkyndt gennem mig, at det ikke er på menneskevis, for fra et menneske har jeg hverken modtaget det eller lært det, men ifølge en åbenbaring fra Jesus Kristus [Gal 1,11-12]." ${ }^{27}$ Men han sagde også, da han skrev til dem, der er i Efesos: "Så sandt I har hørt om forvaltningen af Guds nåde, som er blevet givet mig med henblik på jer, at hemmeligheden er blevet gjort kendt for mig $^{28}$ ved en åbenbaring, ligesom jeg i korte vendinger har skrevet det tidligere, ligesom I kan <kende min visdom i Kristi hemmelighed, idet I læser det $>-{ }^{29}$ den (hemmelighed),

25. "Også": dvs. on, som er i håndskriftet (AT), men som ved en fejl mangler i Lefort (1955).

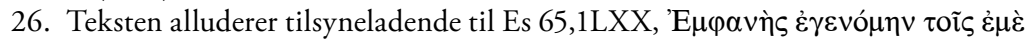

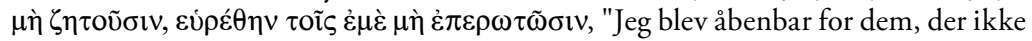
søgte mig, jeg blev fundet af dem, der ikke spurgte efter mig." I Esajas er der tale om ikke at søge og ikke at spørge, i den koptiske tekst at søge og ikke at spørge. Man kunne så formode, at en negation var faldet ud i tekstoverleveringen, men det vil være lidt dristigt, da vi ikke kender den større kontekst, dvs. den foregående del af brevet; jf. Lefort (1955a), 32 n. 1.

27. Citatet følger ret nøje Det sahidiske Nye Testamente (Horner (1911-1924), V, 136), dog med enkelte afvigelser.

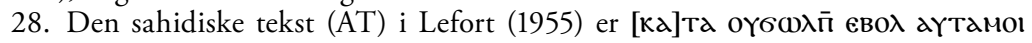
епмнстнріоN, men håndskriftet synes at læse едүтамо, altså en circumstantialis, hvilket det ikke er helt let at give mening til; måske en skriverfejl?

29. Den sahidiske tekst er formodentlig blevet ødelagt ved en afskrivningsfejl og

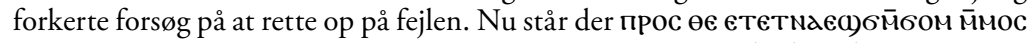

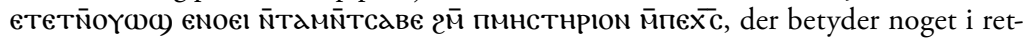
ningen af "alt efter hvad I formår, idet I ønsker at kende min visdom i Kristi hem-

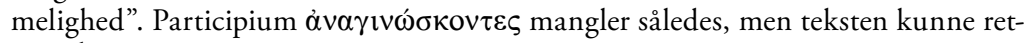

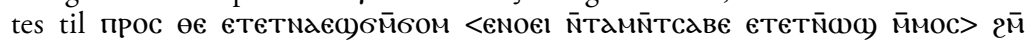
пмнстнріом м̄пе $\overline{x c}$. Den er meget tæt på teksten i Horner (1911-1924), V, 216, der

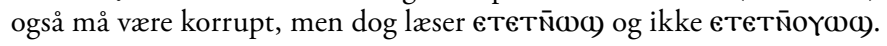


der ikke er blevet åbenbaret for menneskenes børns slægter, sådan som den nu er blevet åbenbaret for hans profeter og hans hellige apostle [Ef 3,2-5]." 30

8 Men det er ikke for dem alene, oh brødre, at Herren er blevet lærer ved at åbenbare hemmeligheden for dem, men han er også lærer for alle os. For ganske vist er Paulus glad sammen med sine disciple, ${ }^{31}$ fordi de således er blevet undervist i evangeliet, men han beder for dem, der er i Efesos, for at "vor Herre Jesu Kristi Gud, herlighedens fader, må give jer visdoms ånd og åbenbaring i hans viden [Ef 1,17]." ${ }^{32}$ Men apostlen ved, at vi alle har del i den bøn, som han gjorde for disse, og ikke kun på den tid, ${ }^{33}$ da Herren åbenbarede viden for menneskene. Og det er også ham, ${ }^{34}$ der irettesætter os $^{35}$ indtil enden, [ham, der lærer] ${ }^{36}$ men[nesket] viden ifølge salmistens ord, ${ }^{37}$ ham, der blev bønfaldt af sine disciple om at lære dem at bede, og det er ham, der dagligt lærer i templet, ifølge det, som Lukas har sagt [jf. Luk 19,47]. Det er ham, hvis disciple sagde til ham: "Lærer, hvornår vil disse ting ske, og hvad er tegnet på, at alle disse ting skal til at fuldendes?"38 Og på det tidspunkt hans disciple spurgte ham, "Hvor ønsker du, at vi skal forberede påskemåltidet, for at du kan spise det [Luk 22,9]?”, ${ }^{39}$ svarede han og sagde

30. I forhold til Det græske Nye Testamente (vers 5), som det foreligger i NA ${ }^{28}$, er rækkefølgen apostle - profeter vendt om og ordene $\dot{\varepsilon} \vee \pi v \varepsilon u ́ \mu \alpha \tau \imath$ udeladt. Den sahidiske tekst i Horner (1911-1924), V, 216 svarer derimod til den græske i NA ${ }^{28}$.

31. Således AT; AS læser: "For sammen med sine glade disciple er Paulus glad (...)" 32. I Det græske Nye Testamente $\left(\mathrm{NA}^{28}\right)$ er der derimod tale om "visdoms og åbenbarings ånd".

33. Således AT; AS læser: "Men han ved, at vi alle har del i den bøn, som han gjorde for dem, der er apostle, og ikke kun på den tid".

34. Dvs. Herren, Jesus.

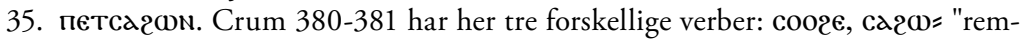
ove" er oftest refleksivt og næppe relevant her. Der kunne derimod være tale om coo2€, cd2 $\omega$ = "be set up, upright", men her foretrækkes coo2€ "reprove, correct"; Crum nævner ganske vist kun status pronominalis $\mathrm{Cd} 2 \omega=\mathrm{i}$ bohairisk, men status pronominalis findes også i sahidisk, som det fremgår af Kasser 60a. At dømme ud fra fotografiet er dette i øvrigt en meget usikker læsning.

36. AS slutter foreløbig her; efter lakuner er dog det løsrevne ord пєттаaץ, "han som giver" med et objekt i pluralis bevaret i håndskriftet (ifølge Lefort (1955), det ser ud fra fotografiet ikke fuldstændig sikkert ud). I AT er der til gengæld her en lakune, men der kan ikke have stået det samme på grund af de følgende bevarede ord, hvor der står et andet objekt, nemlig nсоoүN, "viden".

37. Jf. S1 17,36LXX (der her afviger fra 18,36MT); 93,10LXX (=94,10MT).

38. Athanasios' citat ser ud til at hente det indledende nca2 ("Lærer") fra Luk 21,7, men følger ellers teksten i Mark 13,4, sådan som den findes i Horner (1911-1924), I, 568. Kombinationen af evangelier kan betyde, at der i Athanasios' oprindelige tekst var tale om et citat fra hukommelsen.

39. Citatet har samme form som i Codex Vaticanus ifølge NA ${ }^{28}$, der også svarer til den bohairiske version. Den sahidiske oversættelse af Luk 22,9 følger derimod den

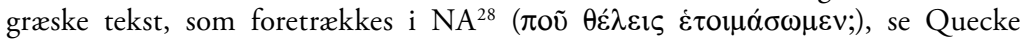
(1977), 252; Horner (1911-1924), II, 408. 
til dem: "Se, når I går ind i denne by, vil en mand møde jer, der bærer en krukke med vand. Følg efter ham til det hus, han går ind i, og sig til husets herre: Det er læreren, der siger til dig: Hvor er min spisesal, det sted, hvor jeg vil spise påskemåltidet sammen med mine disciple [Luk 22,10-11]?”

9 Og han talte meget godt på denne måde, for navnet belæring ${ }^{40}$ hører til ham, fordi han alene er den sande lærer. For hvem er det, som er troværdig til at lære mennesket om Faderen, hvis ikke han, som altid er i hans skød [jf. Joh 1,18]? Og hvem er det, som kan overtale dem, som han underviser, om "de ting, som et øje ikke har set, og et øre ikke har hørt, og som ikke er steget op i menneskehjertet" [1 Kor 2,9], hvis ikke han, som alene kender Faderen [jf. Matt 11,27]? Og han har anlagt vejen, så vi kan gå ind i himlenes rige. ${ }^{41}$ Derfor har han givet sine disciple en befaling, sådan som Matthæus har sagt det: "Lad jer ikke selv blive kaldt rabbi, for én er jeres lærer, $<$ men $>{ }^{42}$ I er alle brødre, og kald ikke nogen jeres fader ${ }^{43}$ på jorden, for én er jeres fader, som er i himlene. Lad jer ikke kalde lærer, for der er én, som er jeres lærer, Kristus. Men den store blandt jer skal være tjener for jer [Matt 23,8-11].”

10 Men det, som ikke er passende, oh brødre, er, at I lytter til de hellige ord i ligegyldighed. Hvorfor kalder apostlen sig nu et sted "hedningernes lærer i troen og sandheden [1 Tim 2,7]", men et andet sted siger han også om Herren, at det er ham, som har givet nogle at være apostle, andre profeter og nogle forkyndere, andre hyrder og lærere [jf. Ef 4,11]? Og Jakob befaler og siger: "Bliv ikke mange lærere, mine brødre, da I ved, at vi alle vil få en stor dom [Jak 3,1]." Men dette har han ikke sagt, som om der ikke er lærere,

40. Det koptiske $\overline{M N T}$ Ta2 betyder "skill" ifølge Crum 384a. Da det koptiske ord er et abstractum, oversætter det muligvis på dette sted det græske $\delta 1 \delta \alpha \sigma \kappa \alpha \lambda i \alpha$. I polemik mod arianeren Asterius Sofisten havde Athanasios tilsvarende hævdet, at som

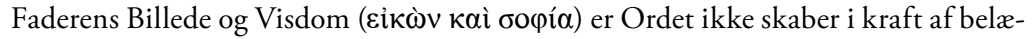

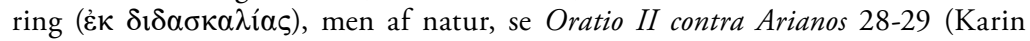
Metzler \& Kyriakos Savvidis (udg.), Orationes I et II contra Arianos, Athanasius Werke I.1.2 (Berlin \& New York: De Gruyter 1998), 205-206)). Tankegangen er i virkeligheden parallel med argumentationen her: Sønnen har ikke modtaget belæring udefra, men giver fra sig selv belæring til menneskene. Oversættelsen "Wisdom" i Brakke (2010) synes dog ikke mulig.

41. Sml. måske Matt 7,14; Joh 14,1-6; Hebr 10,20.

42. Skønt det mangler i AT, foreslår Coquin (1984) her $\langle\lambda \epsilon>$ ud fra Matt 23,8, og et bindeord til at udtrykke modsætningen til den foregående sætning synes også nødvendigt.

43. Ordret "og kald ikke (nogen) fader for jer" (аүळ м̈прммоүтє пнтм єеiळт). Selv om der ikke synes at være nogen betydningsmæssig forskel, er dette næppe en over-

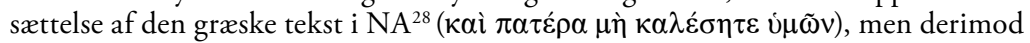

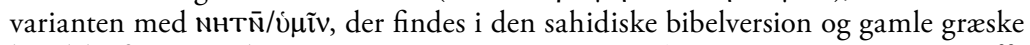
håndskrifter og andre versioner, se Horner (1911-1924), I, 256 og apparatet i NA ${ }^{28}$. 
men tværtimod som om der er nogen, selv om det ikke sømmer sig, at lærere bliver til.

11 Endskønt disse ${ }^{44}$ siger det på denne måde, er det skrevet i evangeliet, at Herren befaler, at vi ikke må lade os kalde rabbi, og ingen må blive kaldt lærer, undtagen Herren alene. Men mens jeg søgte efter disse (bibelsteder), opkom en idé i mit hjerte, som der er brug for, at I undersøger. Dette er det, som jeg har tænkt. Lærerens gerning er at undervise, men disciplenes er at blive undervist. Selv hvis det imidlertid sker, at disse (disciple) underviser, bliver de ikke desto mindre stadig kaldt disciple, for det er ikke dem, som er ophav til de (ord), som de forkynder, derimod tjener de den sande lærers ord. For da vor Herre og vor Gud Jesus Kristus ønskede at oplyse os om dette, sagde han til sine disciple: "Det, som jeg siger jer i mørket, sig det i lyset, og det, som I hører med jeres ører, forkynd det på tagene [Matt 10,27]!”5 For ordene, som disciplene forkynder, er ikke deres egne, men er tværtimod dem, som de har hørt fra Frelseren. Selv hvis Paulus underviser, er det derfor alligevel Kristus, som taler i ham. Og selv hvis Herren siger, ${ }^{46}$ at han har indsat lærere i kirkerne [jf. 1 Kor 12,28], underviser han dem alligevel først og udsender dem derefter.

12 Så er det ganske vist enhvers natur, som er i skabelsen, at modtage undervisning, men vor Herre og vor Skaber er af natur en lærer. For han lærte ikke fra en anden at være lærer, ${ }^{47}$ men selv hvis alle mennesker bliver kaldt "lærere”, er de ikke desto mindre først og fremmest disciple. De underviser også enhver, ${ }^{48}$ fordi Frelseren forsyner dem med Åndens viden, så de alle kan blive mennesker, som er undervist af Gud [jf. Joh 6,45; Es 54,13].

13 Men fordi vor Herre og vor Frelser Jesus Kristus er Faderens Ord, er han ikke blevet undervist af nogen anden, og han alene er retmæssigt ${ }^{49}$ læreren, sådan som jeg har sagt det; ${ }^{50}$ derfor undrede jøderne sig, da de hørte ham, og sagde: "Hvordan kender han skrifterne, <uden at> han er blevet under-

44. Der må menes Paulus og Jakob.

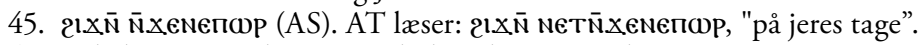

46. Således AT; AS har "Og selv hvis han (= Paulus) siger om Herren", som også kunne være den rigtige tekst.

47. Denne tekst i AS ( $\overline{\mathrm{p}}$ cą); AT læser aȳ cą, hvilket dog er svært at give mening til, måske dog: "For han lærte ikke fra en anden; han var lærer".

48. Således AS; AT: "Men de underviser enhver".

49. AS har korrekt $\Delta$ ıkaı๗0c, og også AT ifølge Coquin (1984), men håndskriftet

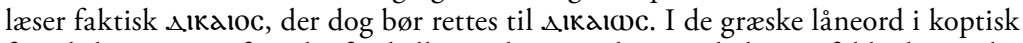
forveksles $\mathrm{o}$ og $\omega$ ofte, idet forskellen på lange og korte vokaler var faldet bort $\mathrm{i}$ det græske talesprog (isokroni).

50. Således AS; AT: "sådan som han har sagt det". 
vist [Joh 7,15]?"51 Derfor ${ }^{52}$ forfulgte jøderne ham, mens han underviste i synagogen og helbredte dem, som var syge. Derfor "har de ikke fra deres fødder til deres hoved manglet ${ }^{53}$ sår eller mærker fra slag, derimod er fræk dristighed af denne slags for dem blevet til et stort vanvid [Es 1,6]." "For de har ikke", ifølge det som er skrevet, ${ }^{54}$ "forstået eller lært visdom, men i mørket vandrer de [S1 81,5LXX (82,5MT)].”

14 Og efter dem har fra hæresierne de elendige melitianere, som har blandet sig med dem, ${ }^{55}$ i deres fornægtelse af ham vandret på steder, som er uden vand, idet de har forladt livets kilde [jf. Joh 4,14]. Selv hvis de for menneskelig æres skyld ${ }^{56}$ hyklerisk taler om påsken, er deres forsamlinger derfor ikke desto mindre et sorgens brød, ${ }^{57}$ fordi de ondskabsfuldt lægger råd op mod sandheden, så at den, som måtte se en sådan forsamling, må sige det ord, som står skrevet og er passende for dem: ${ }^{58}$ "Hvorfor er hedningerne blevet overmodige, og hvorfor tænker folkeslagene på tomme sager [Sl 2,1]?” For på samme måde som Pontius Pilatus samler jøderne sig, og ligesom Herodes samler arianerne og melitianerne sig, ikke for at holde fest, men derimod for at spotte mod Herren, idet de siger: "Hvad er sandheden [Joh 18,38]?" Og "Korsfæst ham, men frigiv os Barabbas [Luk 23,18.21]!" For at sige, at "Guds Søn er en skabning", og "der <var> en tid, da han ikke var", ${ }^{59}$ er

51. AS og AT har her м̄поүтсдвоч, "og han er ikke blevet undervist"; det rigtige synes at være ємпоүтсдвоч, som er teksten i PPalau Rib. Inv.-nr. 183, se Quecke (1984), 121, og som der her er rettet ud fra; jf. også Horner (1911-1924), III, 112.

52. AS har єтвє паї $є є$, "derfor", men AT kun паї $\varsigma \epsilon$, der dog kan betyde det samme.

53. Således AS; AT: "fra deres fødder til deres hoved har de ikke været ladt manglende (...)"

54. AT: ката өє єтсн2. AS's ката пєтснг må betyde det samme.

55. Den knudrede sætningsbygning skyldes vel oversættelsen fra græsk. Det første "dem" (suffikspronomenet =(o) Ү) sigter antageligt til jøderne; hæresierne fortsætter jødernes fornægtelse af Kristus. Det senere "dem" (også suffikspronomenet) henviser derimod snarere til hæresierne. I sit tidlige forfatterskab skelnede Athanasios mellem arianerne, der var hæretikere, og melitianerne, der kun var skismatikere, men i de sene påskebreve opgav han denne skelnen og hævdede, at melitianerne var blevet påvirkede af arianerne (jf. Camplani (1989), 266-270). Meningen her kan derfor være, at melitianerne også er hæretikere, fordi de har blandet sig med arianerne.

56. Således AT; AS: "for menneskenes æres skyld".

57. Sl 126,2LXX (127,2MT); Hos 9,4. - AS's aүळ er måske meningsløst, måske kan der oversættes: "er deres forsamlinger derfor visselig et sorgens brød, (...)"

58. Dvs. melitianerne.

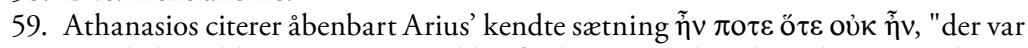
engang, da han ikke var", som også blev fordømt på Nikæa-koncilet i 325. I begge

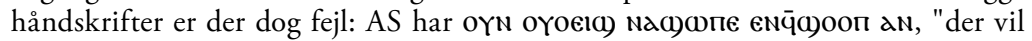
være en tid, da han ikke er." AT har den bedre tekst oүN оүоєı) ()ооп емч̄ळoоп $\mathrm{aN}$, "der er en tid, da han ikke er", der dog må rettes til <N€>OYN OYO€i() ()OOா емч̄ळoоп an, "der < var> en tid, da han ikke var." 
ligesom anmodningen om Barabbas. Hvad angår disse, er det derfor ikke et under, at de er forblevet døde i deres vantro ved at blive bundet i deres onde tanker, ligesom egypterne blev bundet ved deres egne vognaksler. ${ }^{60}$

15 Men hvad angår os, lad os nu endnu en gang holde fest i overensstemmelse med vore fædres overlevering, da vi har ${ }^{61}$ de hellige skrifter, idet de er tilstrækkelige til at undervise os i fuldkommenhed [jf. 2 Tim 3,15-17]. ${ }^{62}$ Netop dem, ${ }^{63}$ - hvis vi læser dem med opmærksomhed og god samvittighed, vil vi blive ligesom det træ, som vokser på de steder, der flyder af vand, og vil bære sin frugt til sin tid, og hvis blade ikke falder af [jf. Sl 1,3].

Men ${ }^{64}$ fordi jeg har sagt, at hæretikerne er tomme, ${ }^{65}$ men vi har skrifterne, indblæst af Gud, ved hvilke vi bliver helbredte [jf. 2 Tim 3,16-17], og jeg frygter, at måske ved en menneskelig list ${ }^{66}$ farer enfoldige mennesker vild, bort fra enkelheden og renheden, som fører til Kristus, ${ }^{67}$ således som Paulus skrev til korinterne, ${ }^{68}$ og derefter begynder at læse i de apokryfe ${ }^{69}$
Gresk. Men fordi vi har omtalt hæretikerne som døde, men os selv som dem, der har de guddommelige skrifter til frelse, og jeg frygter, som Paulus skrev til korinterne, at måske nogle få blandt de enfoldige ved menneskenes list kan blive ført vild fra enkelheden og renheden, og at de derefter vil begynde at beskæftige sig med de andre (tekster), de såkaldte apokryfer, idet de lader sig forlede af,

60. Jf. Ex 14,25; i LXX er der tale om, at Gud binder egypternes vognaksler sammen, så vognene bliver forsinkede.

61. AT læser blot "vi har", men det kan næppe være den oprindelige tekst, da sætningerne så ikke er forbundne.

62. Således AS, der ordret kan oversættes: "idet de er tilstrækkelige for os til at undervise os i fuldkommenhed." $2 \overline{\mathrm{N}}$ oYx menhed" eller "fuldkomment". AT: "idet de lærer os, at de er tilstrækkelige for os til fuldkommenhed."

63. Dvs. de Hellige Skrifter.

64. Her sætter det græske excerpt ind, og da det ofte afviger fra den sahidiske tekst, bringes en separat oversættelse.

65. I det foregående har Athanasios tværtimod sagt, at de er "døde", hvilket svarer til den græske tekst her. Omvendt kunne den sahidiske tekst alludere til SI 2,1, der lige har været citeret i det foregående.

66. Således AS; AT: "ved de ondes list".

67. Således AS; AT: "i retning mod Kristus".

68. Jf. fx 1 Kor 8 og 10; 2 Kor 11,2.

69. AS læser mærkeligt nok her og ellers konsekvent дпокрҮфом, "afskrift" (se videre kap. 16; alle tre steder i kap. 21; kap. 22; kap. 32 - kap. 26, 27 og 28 er ikke bevaret). Det er selvfølgelig en fejl, der er kommet ind i overleveringen. AT har også апографом her og i kap. 16, og første gang i kap. 21, men дпокрүфом anden og tredje gang i kap. 21; kap. 22; kap. 26; kap. 28; i kap. 27 дпогрүфом, der kan bidrage til at forklare fejlens opståen; kap. 32 er ikke bevaret. I kap. 16 oversætter den syriske tekst "skjulte bøger" og tilføjer en forklarende glosse: "som grækerne kalder

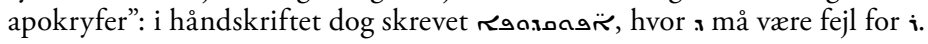


bøger, så de bliver vildførte ved de sande bøgers navn ${ }^{70}$ som om de hører til dem, formaner jeg ${ }^{71}$ jer til at være overbærende, ${ }^{72}$ så at I ser, om de bøger, som I kender, er dem, som jeg skriftligt vil anføre for jer for kirkens kærligheds og nyttes skyld.

16 Og i min beslutning om at huske på dem, ${ }^{74}$ vil jeg benytte eksemplet ${ }^{75}$ fra evangelisten Lukas' evangelium [Luk 1,1-4], idet jeg understøtter min dristighed og selv siger det på denne måde: $<$ Eftersom $>^{76}$ nogle har forsøgt ${ }^{77}$ at skrive for sig selv de bøger, som kaldes apokryfe, ${ }^{78}$ og har at de har samme navn som de ægte bøger, formaner jeg jer til at være overbærende, ${ }^{73}$ hvis I kender disse (skrifter), som jeg skriver om, mens jeg husker det, både for kirkens nød og gavn.

Grask. Mens jeg er i færd med at omtale disse (skrifter), vil jeg, for at styrke mit eget vovestykke, benytte mig af evangelisten Lukas'

70. Således AT; AS: "ved sande bøgers navn".

71. Således AT; AS læser "men jeg formaner", hvilket er svært at give mening til i sammenhængen, da der bør være en eftersætning til det indledende "fordi".

72. Den sahidiske tekst har låneordet anixe (AS)/anexe (AT), som det her formo-

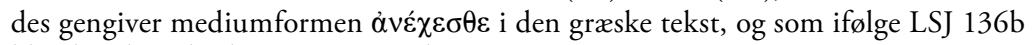
bl.a. kan betyde "bear up (...) with patience".

73. I den græske tekst mangler noget, der svarer til den sahidiske versions м̄тетกิмаY; enten er der tale om den koptiske oversætters tydeliggørende tilføjelse, eller også er en oprindelig konstruktion med ópá $\omega$ faldet bort i løbet af den græske teksts overlevering, således at en emendation burde forsøges.

74. Således AT; AS blot "huske".

75. Ligesom den græske tekst læser AS her TYחoc, mens AT læser ()a גe, "ord".

76. AT læser єпєІАн, og AS єпєІ, som Lefort (1955) ud fra det græske rekonstruerer som $е п є<<\lrcorner н \Pi е р>$, sandsynligvis med rette, selv om det tidlige håndskrift PPalau Rib. Inv.-nr. 181 med den sahidiske oversættelse af Luk 1,1 også har enєl_AH; se Quecke (1977), 25. Udgaven hos Horner (1911-1924), II, 2 bevidner dog anvendelse af låneordet єпєı $\triangle$ нер, og Athanasios-oversætteren har formodentlig gerne villet fastholde allusionen til evangeliet. Det syriske uddrag begynder her.

77. AT er helt bevaret, mens AS mangler ąoine enel, som Lefort (1955) imidlertid allerede rekonstruerede.

78. Fragmenterne af den sahidiske udgave af Pakhoms Liv bringer et citat, som synes at være en harmonisering af denne sætning $i$ kap. 16 og udtryk fra kap. 15 og 21 (Lefort (1933), 283): [х]е аүплассе nаү мпетоүмоүте ероо хе хшоме

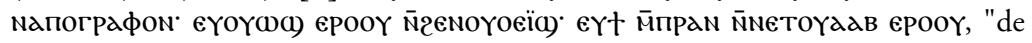
fabrikerede $(\pi \lambda \alpha \dot{\sigma} \sigma \omega)$ for sig selv dem, som kaldes apokryfe bøger, idet de til tider ønskede dem og gav dem de helliges navn." Bemærk, at også her gives den korrupte form дпографом i stedet for дпокрүфом. Den bohairiske udgave (Lefort (1925), 176 1. 21-3) er en oversættelse af den sahidiske og afviger ikke i ordlyd fra denne. 
blandet dem med med skrifterne indblæst af Gud [jf. 2 Tim 3,16], denne (skrift) ${ }^{79}$ om hvilken vi har været enige, - ligesom dem, som har set med deres (egne) øjne fra begyndelsen, idet ${ }^{80}$ de er blevet ord-tjenere, har overleveret den til vore fædre - har det også forekommet mig godt, idet jeg er blevet belært fra begyndelsen ved at nogle vise brødre har opmuntret mig, at jeg fortæller jer om de bøger, som er blevet kanoniseret, idet de er blevet overleveret til os, ligesom der har været tiltro til, at de er fra Gud, så at den, der er blevet bedraget, vil kunne fordømme dem, der har ført ham vild, men den, der er forblevet sund, vil kunne glæde sig, når han minder sig selv om de bøger, der er blevet kanoniserede. eksempel [Luk 1,1-4], ${ }^{81}$ idet jeg også selv siger: Eftersom nogle har forsøgt for sig selv at opstille de såkaldte apokryfer og blande dem med den af Gud indblæste skrift [jf. 2 Tim $3,16]$, som vi er fuldstændig forvissede om, ligesom dem, der blev øjenvidner og tjenere for Ordet fra begyndelsen har overleveret (skriften) til fædrene, har det også forekommet mig godt, idet jeg er blevet tilskyndet af ægte brødre og belært fra begyndelsen, at opstille de bøger, der er kanoniserede og overleverede, og der er tiltro til er guddommelige $^{82}$ i rækkefølge, så enhver, hvis han er blevet bedraget, kan fordømme dem, der vildledte, men den, er er forblevet ren, kan glæde sig over igen at blive mindet om (dem).

79. Den sahidiske teksts mærkelige skift på dette sted fra flertal (skrifterne) til ental tyder på, at den græske teksts ental (skriften) er det oprindelige.

80. Således AS; AT: "og idet".

81. Det græske $\tau$ đó de følgende linjer er der tale om, at Athanasios parafraserer Lukas' prolog, således at hans egen kanonisering og forkastelse af "apokryferne" ses som en slags videreførelse af, at Lukas med sit evangelium ville overgå tidligere fremstillinger af Jesus' liv. Først genbruger Athanasios direkte følgende ord: 'E $\pi \varepsilon \imath \delta \eta \dot{\pi} \pi \varepsilon \rho$... $\dot{\varepsilon} \pi \varepsilon \chi \varepsilon i ́ \rho \eta \sigma \alpha \nu$ $\dot{\alpha} v \alpha \tau \alpha \dot{\xi} \xi \alpha \sigma \theta \alpha \mathrm{l}$, dernæst bruger han samme verbum som Lukas, men giver det en anden betydning: $\pi \varepsilon \pi \lambda \eta \rho о \varphi о \rho \eta \mu \varepsilon ́ v \omega v$, "fuldbyrdede" (ting) i Luk 1,1, svarer til $\dot{\varepsilon} \pi \lambda \eta \rho о \emptyset о \rho \eta ் \theta \eta \mu \varepsilon v$, "vi er fuldstændig forvissede", hos Athanasios. Dernæst indføjer Athanasios atter direkte ord fra Luk 1,2-3 i sin nye sammenhæng: $\kappa \alpha \theta \omega \varsigma s$

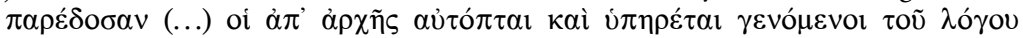

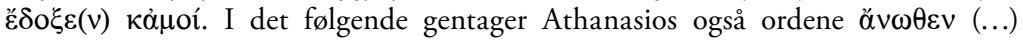
$\kappa \alpha \theta \varepsilon \xi \tilde{\eta} \varsigma$, "forfra (...) i rækkefølge", fra Luk 1,3 med sit ä $v \omega \theta \varepsilon v \dot{\varepsilon} \xi \tilde{\eta} \varsigma$, "fra begyndelsen (...) i rækkefølge". Endelig må íva غ̇ंı

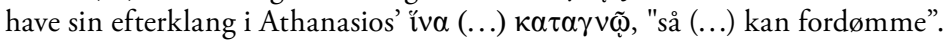

82. Den syriske tekst læser: "de guddommelige skrifter, som bliver overleveret og troet ifølge den hellige kirke". Er "ifølge den hellige kirke" syrerens fortolkende tilføjelse? 
17 De (bøger), der hører til Det Gamle Testamente er ${ }^{83}$ toogtyve i deres antal, for det er dem, som er overleveret os, - ligesom de er hos os, på samme måde hos hebræerne, ${ }^{84}$ men $^{85}$ rækkefølgen af deres oplæsning og deres navne er disse: Den første er Genesis, efter den Exodus, så Leviticus, og efter denne Numeri og Deuteronomium. Dernæst Josua Nuns (søn) og Dommerne og Ruth. Den første bog og den anden regnes som én, og $^{86}$ den tredje og den fjerde regnes som én. $\mathrm{Og}^{87}$ efter disse de to Krønikebøger: De regnes som én. $\mathrm{Og}$ ligeledes også Ezras første og anden bog: ${ }^{88}$ De regnes som én. Efter den Salmernes Bog og Ordsprogene. Så $\mathrm{P}<\mathrm{r}>$ ædikerens Bog og Højsangen,
Grask. I antal er der nu hele toogtyve bøger af Det Gamle Testamente, for jeg har hørt, at det samme antal bogstaver er blevet overleveret hos hebræerne, men efter rækkefølge og navn er hver enkelt således: Først Genesis, ${ }^{89}$ så Exodus, så Leviticus, og efter den Numeri, og derefter Deuteronomium. Og efter disse kommer Josua Nuns (søn) og Dommerne, og efter denne Ruth, og igen derefter Kongernes fire Bøger. Og den første og anden af disse tælles som én bog, og den tredje og fjerde på samme måde som én. ${ }^{90} \mathrm{Og}$ efter disse den første og anden af Krønikebøgerne, der ligeledes atter er talte som én bog. Så Ezra; den første og den

83. I AS er MeN en del af en $M € N-\lambda \epsilon$-konstruktion, mens $\Delta \epsilon$ i det følgende erstattes med rap i AT.

84. Således AT; i AS foreligger nok en korrupt sahidisk tekst, som er svær at oversætte.

85. Således AS; AT: "for".

86. $\Delta \epsilon$ mangler i AS.

87. $\Delta \epsilon$ i AT, skønt glemt i Coquin (1984); mangler i AS.

88. Således AT; i AS blot "ligeledes også den første og den anden bog", som Lefort emenderede: "<Efter den Ezra>, ligeledes også den første og den anden bog". AT har dog snarere den rigtige tekst.

89. I denne oversættelse af Athanasios' græske tekst bruges de almindelige danske navne for Bibelens bøger, dog let tilpasset omstændighederne, således de almindelige latinske betegnelser for Mosebøgerne. LXX og dermed Athanasios benytter disse

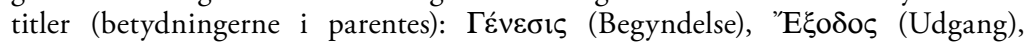

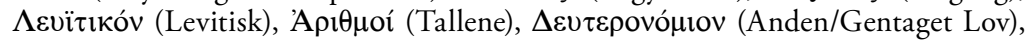

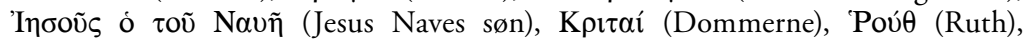

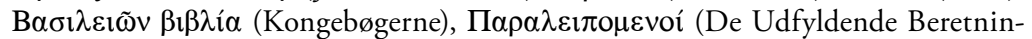

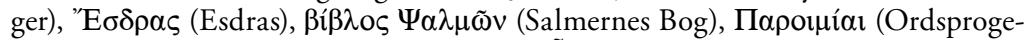

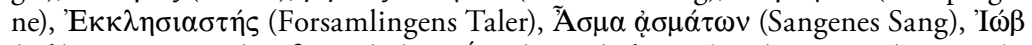

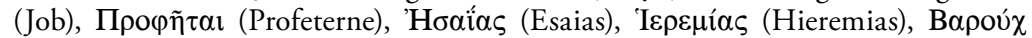

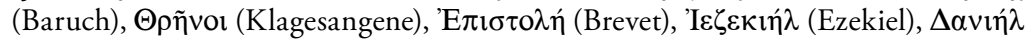
(Daniel). - Den sahidiske oversættelse bruger de græske titler, bortset fra at den oversætter ordene "bog" og "Sangenes Sang". - Den syriske tekst gengiver de gammeltestamentlige bøgers navne, som de er i Peshitta, der er uafhængig af LXX.

90. Dvs. 1-2 Samuelsbog og 1-2 Kongebog. 
og foruden disse også Job. Derefter Profeterne: De Tolv Profeter ${ }^{11}$ regnes som én enkelt bog; efter $<$ dis $>\mathrm{se}^{92}$ Esajas og Jeremias, idet Baruk og Klagesangene og Brevet er knyttet sammen med den; og efter den Ezekiel og Daniel. Indtil dette sted er disse Det Gamle Testamentes bøger. $^{93}$

18 Det sømmer sig ikke, at vi udsætter at nævne Det Nye Testamentes bøger, idet de er disse fire evangelier: Det ifølge Matthæus, det ifølge Markus, det ifølge Lukas, det ifølge Johannes. Så Apostlenes Gerninger og de syv breve, som kaldes katolske, ${ }^{97}$ ét af Jakob, og ${ }^{98}$ to af Peter, tre ${ }^{99}$ af Johannes, ét andet af Judas. ${ }^{100} \mathrm{Og}$ foruden disse fjorten breve af apostelen Paulus, som er skrevet på denne måde i rækkefølge: Det første er det til Romerne, efter anden ligeledes som én. ${ }^{94} \mathrm{Og}$ efter disse Salmernes Bog, og derefter Ordsprogene, så Prædikerens Bog og Højsangen; foruden disse er der også Job. Og derefter Profeterne: De tolv er talt i én bog, ${ }^{95}$ så Esajas, Jeremias og med den Baruk, Klagesangene og Brevet, ${ }^{96}$ og efter Ezekiel også Daniel. Indtil disse er Det Gamle Testamentes bøger opstillet.

Grask. Igen bør man ikke tøve med at nævne Det Nye Testamentes bøger. For det er disse: Fire evangelier, ifølge Matthæus, ifølge Markus, ifølge Lukas og ifølge Johannes. Så efter disse Apostlenes Gerninger og apostlenes syv breve, kaldet katolske, ${ }^{101}$ således: Af Jakob ét, og to af Peter, så tre af Johannes, og efter disse ét af Judas. Foruden disse er der apostelen Paulus' forten breve, skrevet således i rækkefølge: Først, til Romerne, så to til Korinterne, og

91. Således AT; AS blot: "Tolv Profeter".

92. Således AS; AT: "den".

93. Således AS; AT: "Indtil dette sted er Det Gamle Testamentes bøger".

94. Ezras Bog og Nehemias' Bog i MT findes ikke som sådan i LXX, der i stedet har to Ezrabøger, som Athanasios må sigte til: Som regel betegner 1 Ezra eller

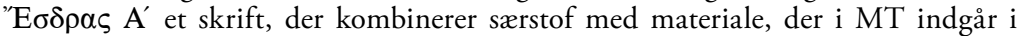
Krønikebøgerne og i Ezras Bog og Nehemias' Bog; i Vulgata kaldes dette skrift 3 Esdras, og under denne titel er det oversat til dansk af Erling Hammershaimb i idem m.fl., De gammeltestamentlige Pseudepigrafer $i$ oversattelse med indledning og noter, 2. udg., København: Det Danske Bibelselskab 2001, 341-380. 2 Ezra eller

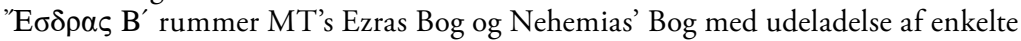
vers fra den sidstnævnte. I nogle græske håndskrifter er rækkefølgen af disse to Ezrabøger dog byttet om.

95. Dvs. de såkaldte "små" profeter.

96. Athanasios forstår altså Jeremias' Bog som bestående af fire dele: Jeremias' Bog, Klagesangene, som traditionen tilskrev Jeremias, samt Baruks bog og Jeremias' Brev, der i luthersk tradition er gammeltestamentlige apokryfer.

97. Således AT; AS: "de syv katolske breve".

98. Således AT; "og" $(\Delta \epsilon)$ mangler i AS.

99. Således AS; AT: "men tre".

100. Således AS; AT: "ét andet, som er det af Judas".

101. Græsk: Almindelige. - Bestemmelsen "katolsk" mangler i den syriske oversættelse. 
det de to til Korinterne, ${ }^{102}$ så det til Hebræerne, så det til Galaterne og det til Efeserne, så det til Filipperne og $^{103}$ det til Kolosserne, efter disse de to til Thessalonikerne, efter dem $^{104}$ de to til Timotheus og $^{105}$ det til $\mathrm{Ti}$ tus, og ${ }^{106}$ til slut det til Filemon. Og efter disse Johannes' Åbenbaring.

19 Disse er frelsens kilder, må den tørstende derfor nyde ordene, som er i dem! Fromhedens lære, som er i dem, bliver prædiket; ${ }^{108}$ ingen må føje (noget) til disse (bøger), og man må ikke fjerne (noget) fra dem. ${ }^{109}$ For på grund af dem bebrejdede Herren saddukæerne, ${ }^{110}$ da han sagde: "I farer vild, så I hverken kender skrifterne eller Guds kraft [Matt 22,29]." 111 Og han belærte også jøderne, idet han sagde: "Gransk skrifterne, for det er dem, som vidner om mig [Joh 5,39]!”112 efter disse til Galaterne, og dernæst til Efeserne, så til Filipperne og til Kolosserne, og efter disse to til Thessalonikerne, og det til Hebræerne, ${ }^{107}$ og straks dernæst to til Timotheus og ét til Titus, og til sidst det ene til Filemon. Og yderligere Johannes' Åbenbaring.

Grask. Disse er frelsens kilder, så at den tørstende kan blive fyldt af de ord, ${ }^{113}$ der er i dem. I disse (bøger) alene prædikes fromhedens lære. Ingen må føje (noget) til dem, heller ikke må man fjerne noget fra dem. Herren fik saddukæerne til at skamme sig over dem, da han sagde: "I farer vild, for I kender hverken skrifterne eller deres kraft [Matt 22,29]", og han advarede jøderne: "I gransker $^{114}$ skrifterne, for det er dem, der vidner om mig [Joh 5,39].”115

102. Således AT; AS: "Korint".

103. Således AS; AT: "så".

104. Ordret: "Efter det".

105. Således AS; AT: "så".

106. Således AT; "og" $(\lambda €)$ mangler i AS.

107. Den syriske tekst har Hebræerbrevet på samme plads som den græske.

108. Således AS; AT: "Fromhedens lære bliver prædiket i dem".

109. Jf. Deut 4,2; 13,1; Åb 22,18-19.

110. Således AS; AT: "Det var på grund af disse, at Herren bebrejdede saddukæerne".

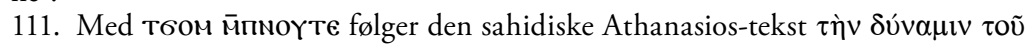

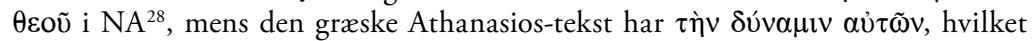
også synes at passe bedre ind i Athanasios' kontekst. Den syriske version udelader leddet "eller deres kraft"/"eller Guds kraft".

112. Citatet afviger stærkt fra den form, det har i NA ${ }^{28}$.

113. Den syriske oversættelse har her "livets ord", jf. måske vandet til evigt liv i Joh 4,13-14.

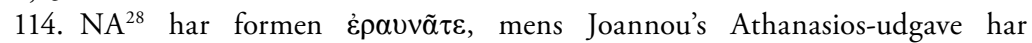
'E $\varepsilon v v \tilde{\alpha} \tau \varepsilon$. Ifølge Bauer 606 er formen med $\varepsilon$ den klassiske; foretrak Athanasios eller de senere byzantinske samlere denne form?

115. Citatet afviger stærkt fra den form, det har i NA ${ }^{28}$. 
20 Men for at jeg må styrke jer meget, vil jeg føje dette andet nødvendige ord til dem, som jeg har sagt: Der eksisterer andre bøger ud over disse; de er ikke blevet kanoniseret, men de er af vore fædre blevet bestemt til, at dem, der vil indtræde som nye og ønsker at lære fromhedens ord, må læse dem: Salomons Visdom og Siraks Søns Visdom og Ester og Judit og Tobias og Apostlenes Belæring ${ }^{116}$ - jeg mener ${ }^{117}$ ikke den, om hvil$\mathrm{ken}^{118}$ man siger, at den fordømmer Deuteronomium - og også Hyrden.

21 Alligevel, oh mine elskede, ved at vore fædre lod de første af bøgerne kanonisere, ${ }^{123}$ men så bestemte om disse ${ }^{124}$ at lade dem blive oplæst, har de overhovedet ikke haft noget apokryft ord i tankerne: Denne falskhed, som blev nævnt i det foregående, hører derimod til hæretiker-
Grask. Men for større nøjagtigheds skyld tilføjer jeg også dette, idet jeg skriver af nødvendighed, at der også er andre bøger ud over disse, der ganske vist ikke er kanoniserede, men er dannet af fædrene til at blive læst op for dem, der er kommet til for nylig og ønsker at blive oplært om fromhedens ord: ${ }^{119}$ Salomons Visdom og Siraks Visdom og Ester og Judit og Tobias ${ }^{120}$ og Læren, der kaldes Apostlenes, ${ }^{121}$ og Hyrden. ${ }^{122}$

Grask. Og alligevel, elskede, er de førnævnte kanoniserede, og disse er oplæste, og intetsteds er der omta$1 \mathrm{e}^{125}$ af apokryfer; ${ }^{126}$ det er derimod hæretikernes opfindelse,

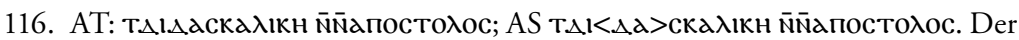

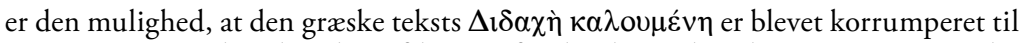

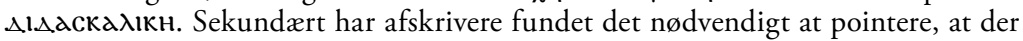
ikke tænkes på den syriske Didascalia Apostolorum, fordi denne kritiserer Deuteronomium.

117. c)axe, "tale", kan også betyde "mene", jf. eksempler fra Shenoute i Crum 613a. Jf. at græsk $\lambda \varepsilon ́ \gamma \omega$ også kan betyde "mene" (LSJ 1034, III 9; 1 Kor 10,29).

118. epoc mangler i AT, men bør nok være med.

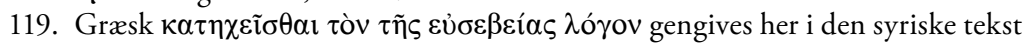

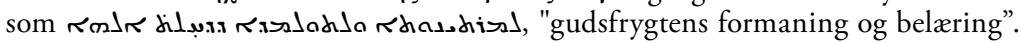
Måske er "formaning og belæring" en hendiadys-oversættelse, men "gudsfrygt" i stedet for "fromhedens ord" må formodentlig være en variant, der ikke er opstået gennem oversættelse.

120. Dvs. Tobits Bog.

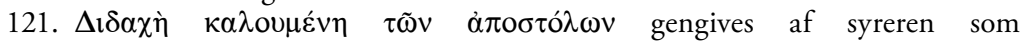

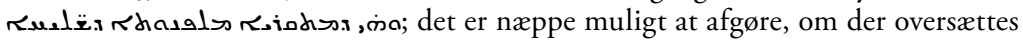
fra $\Delta \mathrm{l} \delta \alpha \chi \eta ́$ eller $\Delta \mathrm{l} \delta \alpha \sigma \kappa \alpha \lambda \iota \kappa \eta$.

122. Dvs. Hermas' Hyrden.

123. Således AS; AT: "efter at vore fædre lod de første af bøgerne kanonisere".

124. Dvs. disse andre ikke-kanoniserede bøger, omtalt umiddelbart før i kap. 20.

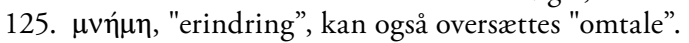

126. Syreren har denne forklarende oversættelse: "skjulte bøger, dem som af grækerne kaldes apokryfer". 
ne. ${ }^{127}$ For de er dem, som skriver dem på det tidspunkt, som de $\mathrm{d}^{128}$ vil, og tillægger dem alder, så at de kan offentliggøre dem som gamle ${ }^{129}$ og kan finde en måde at bedrage disse enkle. idet de skriver dem, når de vil, men tildeler og giver dem dateringer, ${ }^{130}$ så at de ved at føre dem frem som gamle har et påskud fra dette til at bedrage de enfoldige. ${ }^{131}$

Men stor er hårdhjertetheden hos dem, som laver disse (apokryfer), og som ikke er bange for ordet, som står skrevet: "I må ikke føje (noget) til det ord, som jeg befaler jer, heller ikke skal I tage (noget) fra det [Deut 4,2]!" Hvem er det, som har ladet de enkle tro, at de bøger er af Enok, eftersom der ikke var skrift før Moses? ${ }^{\text {132 }}$ Ud fra hvad kan man sige, at Esajas har en apokryf bog? Det er ham, der på de høje bjerge åbent forkynder [Es 40,9] og siger: "Jeg taler ikke i hemmelighed, heller ikke på en mørk jords sted [Es 45,19]." 133 Hvordan kan Moses have en apokryf bog? Det var ham, der fremførte Deuteronomium, idet han tog himlen og jorden til vidner [jf. Deut 4,26; 30,19; 31,28].

22 Denne sag er tværtimod ikke noget andet ${ }^{134}$ end kløen af ører [jf. 2 Tim 4,3] og handel med fromhed [jf. 1 Tim 6,5] og at behage kvinderne [jf. 2 Tim 3,6]. Men Paulus talte forud om mennesker af den slags, ${ }^{135}$ idet han skrev til sin discipel: "Der vil komme en tid, hvor de ikke vil billige den sunde lære, men tværtimod skabe lærere for sig selv efter deres egne viljer, ${ }^{136}$ idet deres ører bliver kløet, og de vil dels vende deres ører væk fra

127. Således AS; AT’s let afvigende tekst er svær at give mening til; måske: "derimod denne ovennævnte falskhed, idet den er en ting, der hører til hæretikerne".

128. етоү<о $>\boldsymbol{1}$ ) ; denne rettelse (i Lefort (1955)) er næppe nødvendig, da man kunne "forkorte" sådan.

129. Således AT; AS: "(som) fra de gamle".

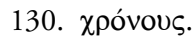

131. Her slutter både det græske og det syriske uddrag.

132. Jakob af Edessa bringer i sin diskussion af Enoks bog et citat af denne sætning

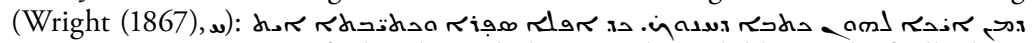

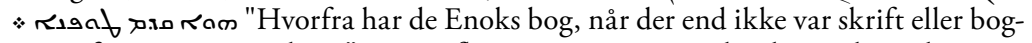
staver før oversvømmelsen?” Der er flere ting, som er værd at bemærke ved citatet. Det synes at blande sætningen med den efterfølgende, hvor der netop retorisk spørges, hvorfra Esajas har en bog. Derudover taler Jakob om en specifik Enoks bog, og altså ikke generiske "Enoksbøger". Da Jakob fremhæver Judasbrevets citat af Første Enoksbog (Jud 14-15) i sin argumentation, må der hos Jakob være tale om Første Enoksbog. Til sidst har citatet "før oversvømmelsen" i stedet for den koptiske teksts "før Moses". Dette er bemærkelsesværdigt, eftersom Jakob i sit brev til stylitten Johannes netop forsøger at besvare spørgsmålet "om det, som siges, er rigtigt, at der ikke var skrift eller bogstaver før Moses." Derfor er det ikke usandsynligt, at Jakob her har bevaret en variant, der forelå i tekstoverleveringen af Athanasios' påskebrev. Et lignende argument for ægtheden af Enoks bog finder man allerede hos Tertullian (De cultu feminarum I,3).

133. Således AS; AT: "heller ikke på et mørkt sted".

134. Således AS; AT: "et andet".

135. Således AS; AT: "en sag af den slags".

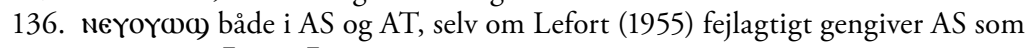

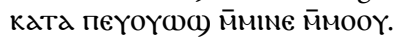


sandheden, dels ${ }^{137}$ gå til fabler [2 Tim 4,3-4].” For apokryferne er i sandhed fabler, og tilliden til dem er en tom gerning, fordi de er tomme og besudlede stemmer. ${ }^{138}$ For disse (apokryfer) er begyndelser til borgerkrig, og den form for hensigt ${ }^{139}$ er kamp mellem mennesker, idet de ikke søger det, der er godt for kirken, men derimod begærer at modtage æresbevisninger fra dem, som de narrer, så at de ${ }^{140}$ ved at høre nye ord ${ }^{141}$ vil tænke, ${ }^{142}$ at de $^{143}$ er store.

23 Mon da ikke det sømmer sig for os at afvise denne slags bøger? ${ }^{144}$ For selv hvis et nyttigt ord findes i dem, er det alligevel ikke godt at tro dem. For dette er et listigt træk hos dem, der har fundet på dem med henblik på at blande dem med et enkelt ord, som er nyttigt, eller to, så at de gennem den slags bedrag kan finde en måde at skjule deres onde lærdomme, som de åbenlyst har opfundet. Mon ikke det derfor sømmer sig endnu mere, at vi afviser (apokryferne)? Og lad os pålægge os selv ikke at forkynde noget fra dem og ikke at tale fra dem sammen med dem, der ønsker at blive belært, selv hvis der er et ord i dem, som er nyttigt, sådan som jeg (allerede) har sagt det. For hvad er det, som de åndelige skrifter mangler, så at vi skulle opsøge disse tomme stemmer fra fremmede mennesker? Det er en passende ting, at vi fremfører det ord, som er skrevet imod dem: "Men er der ikke harpiks i Galaad, eller er der ikke en læge på det sted [Jer 8,22]?” Og også: "Hvad gavn for dig er Egyptens vej, så du drikker vand fra Gêon [Jer 2,18], som er grumset?"145 Og også: "Hvad gavn for dig er Assurs vej, så du drikker vand fra deres floder [Jer 2,18]?"146

137. Således AT; "dels" ( $\Delta €$ i en M€N- $\Delta €$-konstruktion) mangler i AS.

138. Ifølge Coquin (1984) læser AT her (meningsløst) оүвнт i stedet for єүвнт, men det er ikke rigtigt: Både AS og AT har (rigtigt) еүвнт.

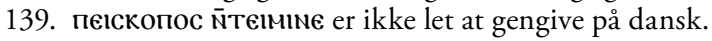

140. Dvs. de bedragne.

141. Således AT ("ved deres høren nye ord"); AS: "så at de ved deres frembringelse/ proklamation af nye ord".

142. AS har her єүємєєүє єрос хє, "vil tænke det:"; AT har (ikke noteret i Coquin (1984)) єүємєүє єроо Х $€$ - måske refleksivt (jf. Crum 199b): "vil tænke sig".

143. Dvs. bedragerne.

144. Således AS; AT: "denne slags ord".

145. паl еттн2 betyder ordret "som er blandet", og det kunne også oversættes "som er i oprør" (dvs. uroligt). Det synes at være Athanasios' tilføjelse, i hvert fald mangler disse ord i LXX.

146. De tre citater fra Det Gamle Testamente skal udtrykke, at kirkens kanoniske skrifter er tilstrækkelige, så man ikke behøver at søge andre steder hen; i intention svarer de til en vis grad til det danske ordsprog "gå ikke over åen efter vand"; Athanasios' mening er dog, at det, som apokryferne bringer, er ringere, end hvad man kan finde i kirkens skrifter. 
24 For hvis der på den ene side spørges om troen, er det muligt for os at kende den gennem dem, ${ }^{147}$ det vil sige, (at) vi tror på Faderen og Sønnen og Helligånden. (Hvis man) på den anden side (spørger) om hans menneskelighed, udråber Johannes: "Ordet blev kød og boede hos os [Joh 1,14]." Og (hvis man spørger) om opstandelsen, beskæmmede Herren saddukæerne, da han sagde: "Læser I ikke det, som er blevet sagt til jer af Gud, idet der siges: 'Jeg er Abrahams Gud, Isaks Gud, Jakobs Gud'? Han er ikke Gud for dem, som er døde, men derimod for dem, som er levende [Matt 22,31-32].” Og (hvis man spørger) om dommen, som vil finde sted, så ${ }^{148}$ står der skrevet, at "Vi vil alle stå for Kristi domstol, så at enhver vil få de ting gennem sit legeme i forhold til de ting, som han har gjort, enten gode eller onde [Rom 14,10 og 2 Kor 5,10]."149

25 Gennem disse ${ }^{150}$ har manikæerne afsløret, at de er ugudelige, når de lytter til dem, eftersom de ${ }^{151}$ råber $^{152}$ om Gud: "[Han har] skabt jorden som intet [Es 40,23LXX]," og også: "Hvem er det, som har skabt alle disse ting [Es 40,26]?" Og også: "Vi ved, at verdenerne er blevet forberedt ved Guds Ord, at det, som vi ser, er blevet til fra det, som ikke er til [Hebr 11,3]." Det er også sådan, at Markion har afsløret, at han ikke ved, at "loven er hellig, og buddet er helligt, og det er retfærdigt, og det er godt [Rom 7,12]", særligt da Frelseren sagde: "Hvis I havde troet på Moses, ville I have troet på mig, for han har skrevet om mig" [Joh 5,46], og også: "Gransk skrifterne, for det er dem, som vidner om mig [Joh 5,39]!”'153 Og det er også de hellige skrifter, som har afsl[øret] dem, som er i F<r $>y[$ gi] $]$ en, ${ }^{154}$ - for de er [hæ] retikere - da

147. Dvs. de kanoniske skrifter.

148. Egentlig står der rap i teksten, men det udgør et problem, da det jo skulle stå som andet ord i en ny hovedsætning. Her er der søgt en oversættelse ud fra den antagelse, at sætningen, parallelt med de ovenstående sætninger indledt med єтвє, skal forstås som apodosis til den protasis, som implicit er videreført fra begyndelsen af kapitel 24. 149. Det meningsløse пєөon i håndskriftet (AT) må rettes til пєөо<оү>, "onde", jf. Elanskaya (1994), 381. Stadig giver teksten ikke mening, og Athanasios må tænkes at have fulgt den græske tekst til 2 Kor 5,10, men AT følger den sahidiske version af 2 Kor 5,10, som den fx foreligger i Herbert Thompson, The Coptic Version of the Acts of the Apostles and the Pauline Epistles in the Sahidic Dialect (Cambridge: Cambridge University Press 1932), 153.

150. Dvs. skrifterne. I håndskriftet (AT) står derefter de slettede ord "for gennem disse" (dittografi).

151. Dvs. skrifterne.

152. Dvs. hvis vi her, som foreslået af Camplani (2003), 514 n. 30 læser Фа) єво入̣. Teksten hos Elanskaya (1994), 379 er W0 epọ̣, der ville give oversættelsen "læser til os".

153. Citatet afviger stærkt fra den form, det har i NA ${ }^{28}$. Også citeret ovenfor af Athanasios i kap. 19.

154. Rettelse og rekonstruktion foreslået af Lucchesi (2001), 258 n. 17; Elanskaya (1994), 379, 381) læste тефү[cı]d og foreslog det rettet til тефү[ст]<c $>$, hvilket ville give "dem, som er i/fra natu[ren]". Athanasios må her tænke på montanisterne. 
Helligånden kom ned over disciplene, [o]g de gav den [til de kr]istne [jf. ApG 2,2-4]. Men også ari[anerne] sammen med deres snyltere me[li]tianerne blev [be]skæmmet, da Johannes tænkte på deres ugudelighed, at "der < var> en tid, da Sønnen ikke var", 155 og han afviste den ved denne røst: "I begyndelsen var Ordet, og Ordet var hos Gud, og Ordet var Gud [Joh 1,1]".

26 Derimod sagde han, ${ }^{156}$ at Paulus har modtaget et vidnesbyrd fra apokryferne, når han siger: "De ting, som et øje ikke har set, og et øre ikke har hørt, og som ikke er steget op i menneskehjertet [1 Kor 2,9]". 157 Jeg vil svare ham, at denne sag er en, der hører til kværulantiske mennesker. Ikke gennem (tilfældige) ord indfører Paulus sine ord, men tværtimod ${ }^{158}$ er det de ord, som står skrevet i skrifterne, hvis betydning ${ }^{159}$ Paulus har samlet og skrevet. Og man vil være i stand til at forstå dette gennem profeternes ord. For de ord, som er skrevet i Esajas, (er): "De døve vil på den dag lytte til bogens ord, og de blindes øjne, som er i mørket og tågen, vil se, og de, som ikke har et håb blandt menneskene, vil blive fyldt med glæde [Es 29,18-19]", ${ }^{160}$ - det er disse ting, som et øje ikke har set, og disse ting som et øre ikke har hørt, og de er ikke steget op til menneskenes hjerte [jf. 1 Kor 2,9]. ${ }^{161}$ For hvornår har en blind eller en døv håbet at høre eller s[e] Gud, mens de er [i live] blandt menneskene [jf. Es 29,18-19]? ${ }^{162}$ Eller hvem blandt dem, som ikke har et håb, vil overhovedet blive i stand til at tænke, at Or$\operatorname{det}^{163}$ vil blive kød [jf. Joh 1,14]? Eller er de (tanker), som er i Guds hjerte, steget op til menneskenes hjerte [jf. 1 Kor 2,9]? ${ }^{164}$ [Eller] hvornår kender nogen [i si]t hjerte ${ }^{165}[\quad]^{166}$

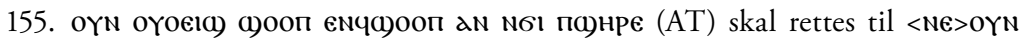
оүоєі() ()ооп емч()оOп аN NGI па)неє, jf. ovenfor note 59.

156. Det er ikke klart, hvem der sigtes til her. Arius eller Melitius? Eller er nogle ord glemt af skriveren? - Lucchesi (2001), 259 foreslår, at der menes Markion; Camplani (2003), 515 n. 34 "generiske hæretikere"; Brakke (2010), 50: "the singular here is a mistake (...) there should be a plural: 'they have said' and 'I will answer them."” 157. Også citeret ovenfor i kap. 9.

158. Elanskaya (1994), 380 læser her 2̣̣ ̣̣, vel det græske $\tilde{\omega} \delta \varepsilon$, så vi ville få teksten "er tværtimod således i skrifterne", men snarere er der tale om en slettet dittografi, nemlig ordene 2NNe, "i dem", jf. Brakke (2010), 64.

159. "Betydning" gengiver det græske låneord voũ (п€үNoүc).

160. Es 29,18 er også et af de steder, som der hentydes til i Matt 11,5/Luk 7,22; i kap. 6 hentydede Athanasios til dette sted i evangelierne.

161. Citeret ovenfor i dette kapitel og i kap. 9.

162. Citeret lige før.

163. Her det græske låneord (п入огос), ellers oversættes der пœ)גхє.

164. Citeret og alluderet til ovenfor i dette kapitel og citeret i kap. 9.

165. Lefort (1955), 60 n. 96 henviser til Rom 11,34; 1 Kor 2,16, men det er tvivlsomt, da der ikke disse steder er tale om at kende Guds voũ $i$ sit hjerte.

166. Seks linjer mangler, jf. Lefort (1955). 
27 [ ] Paulus ${ }^{167}$ [ ] dem som [ ] og ${ }^{168}[\mathrm{t}] \operatorname{alt}^{169}$ ] de [ ] og: "D[isse er d]e ting, som han har forkyndt", [eller "ligeso]m han har sa[gt det", ${ }^{170}$ eller] "[men] Esaj[as går s]å vidt, at han siger det", ${ }^{171}$ [o]g: "ligesom David siger det", ${ }^{172}$ og også: "Moses siger det fra begyndelsen", ${ }^{173}$ igen også: "skriften siger, at Elias". ${ }^{174}$ Selv om han siger, "ligesom det står skrevet", så afslører han ikke, hvor ordet står skrevet, eller hvem det er, som har forkyndt det. Vi derimod, som læser, vi ved, hvor det står skrevet i skrifterne. Og dette ord: "De ting, som et øje ikke har set [1 Kor 2,9]", ${ }^{175}$ finder vi ikke skrevet i skrifterne, ligesom det er. ${ }^{176}$ Men hvis det også står skrevet ${ }^{177} \mathrm{i}$ apokryferne, som hæretikerne siger, så har de, som har opfundet dem, stjålet fra Paulus' ord og skrevet det længe efter.

28 Fordi den sag nu er gjort tydelig, at det vidnesbyrd, som er i apokryferne, er overdrevent, da det er grundløst - for skriften er fuldkommen i alting - så lad underviseren undervise fra skriftens ord, og når dem, der ønsker at modtage undervisning, har nået den passende alder, så lad underviseren præsentere dem for skriftens ord. Det er ikke det rette for dem, som vil begynde at blive belært som katekumener, at $\mathrm{de}^{178}$ forkynder de ord, som er skjulte i skriften som en hemmelighed, men (det er heller ikke rigtigt), at de

167. Athanasios fortsætter i kap. 27 med at bringe citater fra skriften, men pga. kapitlets fragmentariske tilstand, kan de kun i nogle tilfælde lokaliseres.

168. Fejlagtigt angiver Lefort (1955), at $\overline{\mathrm{N}} \mathrm{q}$... er en rekonstrueret lakune; bogstaverne er bevaret. Det må vel være en konjunktiv, der fx kan være videreførende.

169. Dvs. [2P]нтом[, altså det græske ṕๆóv; fejlagtigt gengiver Lefort (1955) sin rekonstruktion som [2P]н[тоN].

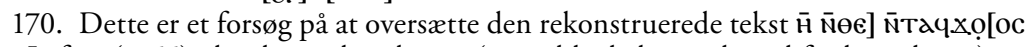
i Lefort (1955), der dog virker dristig (men ikke helt umulig ud fra konteksten) og desuden må rumme en grammatisk fejl. Igen sætter Lefort klammerne forkert, så man ikke kan se, hvad der er bevaret tekst, og hvad der er rekonstruktion; her er det rettet.

171. Lefort (1955) har teksten a)]аpe hCal[ac emiтl]Ma N̄yxooc[, "Esaj[as bebre]jder og siger det". Camplani (2003), 516 henviser til Rom 10,20 ('Hбaías $\delta \dot{\varepsilon}$

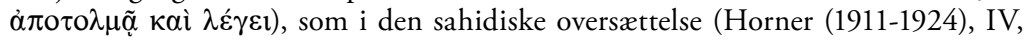

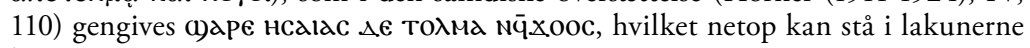
her.

172. Camplani (2003), 516 henviser til Rom 4,6; 11,9.

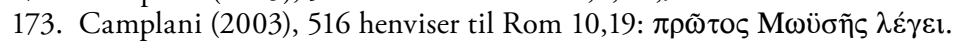

174. Camplani (2003), 516 henviser til Rom 11,2.

175. Citeret ovenfor i kap. 9, og citeret og alluderet til i kap. 26. Athanasios må her også tænke på den afvigende form i Es 64,3.

176. Der er kun svag evidens for o† $\overline{\mathrm{N}}$ - i Crum 83-84, 215-216 (kun ét eksempel). 177. Teksten yonz hos Lefort (1955) betyder "hvis det er levende". Camplani (2003), 516 oversætter "Se poi si trova chiaramente", men angiver ikke, hvilken koptisk tekst, der intenderes, men måske mener han $40<\gamma \omega>$ N2, "<forekommer>". Brakke (2010), 65 n. 90 gætter på teksten чcH2, hvilket ud fra fotografiet synes muligt og her følges.

178. "De" må her sigte til underviserne. 
er tavse om den lære, som de drager nytte af, denne lære, som vil oplyse dem om, på hvilken måde de skal hade synden og lægge afgudsdyrkelsen bag sig som en afskyeligh[ed.] Lære[n ] vide [ ]-dommen [ ] ${ }^{179}$

29 [ ] $]^{180}$ guld (?) $)^{181}$ [ a]nstø[d (?) ] det står skrevet [ ] han som er ham $\left[\right.$ næ] st ... ved det, som hans tanker ${ }^{182}[$ ]

(30-31 er fuldstændig forsvundet.)

32 [ ] i skrifterne. Jeg har været tilfreds med, at disse ting får jer til at huske, så at I, ved at I har de hellige som eksempel, ${ }^{183}$ og ved at I agter de hellige skrifters ord vel, senere skal høre: "Godt, gode og tro tjener! Fordi du var tro i små ting, vil jeg sætte dig over større [Matt 25,21.23].” For disse ting har jeg ikke skrevet, som om jeg var lærer, for jeg har ikke nået det fulde mål af alder. ${ }^{184}$ Derimod, dengang jeg hørte, at hæretikerne, men især disse elendige melitianere, roser sig selv over de bøger, som de kalder "apokryfe", ${ }^{185}$ derfor ${ }^{186}$ har jeg fortalt jer alle de ting, som jeg har hørt fra min fader, ${ }^{187}$ ligesom hvis jeg var hos jer, og I var hos mig i ét eneste hus, ${ }^{188}$ det vil sige "den levende Guds kirke, sandhedens søjle og fasthed [1 Tim 3,15]." Lad os, ved at komme sammen på et enkelt sted, rense denne (kirke)

179. Efter linjen med тмN̄Ṭ[, der må være et koptisk abstrakt substantiv, som vi derfor oversætter "-dommen", regner Lefort (1955) med en linje med ét bogstav bevaret og derefter fire helt forsvundne linjer.

180. Tre linjer med enkelte bogstavspor bevaret.

181. Dvs. N[о]ҮḄ[, men bogstaverne kunne også skilles, så intet meningsfuldt ord er bevaret.

182. Således den koptiske tekst i Lefort (1955); hans franske oversættelse (1955a), 39 med n. 41a rekonstruerer imidlertid den koptiske tekst, så den kan oversættes således: "[som] står skrevet [: 'Ve d]en, s[om vil give] ham, som er ham [næ]st, en ødelæggelse at drikke', ved det, som hans tanker [ ]". Denne tekst henfører Lefort til Hab 2,15, men den genfindes ikke helt sådan i LXX.

183. Crum 94b: kळ "with dat, have, get, keep". Men måske kunne man også oversætte "at I sætter hellige eksempler for jer selv."

184. Ordret: "disse mål af denne alder."

185. Shenoute (Contra Origenistas $\$ 319$ ) bringer et noget tillempet citat af disse

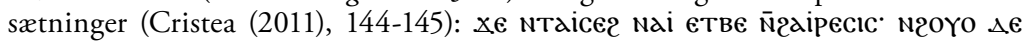

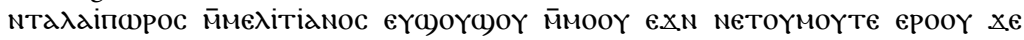
дпокрүфон;, "Angående hæresierne har jeg skrevet disse (ord), men særligt de elendige ( $\tau \alpha \lambda \alpha i \pi \omega \rho \circ \varsigma)$ melitianere, idet de roser sig af dem, som kaldes apokryfer."

186. етвє паї, som dog står mistænkeligt: етвє паї мемтаıсотмоү тнроҮ skal måske rettes til етвє naï еnтaıcotmoY тнроү, "på grund af alle de ting, som jeg har hørt", eller noget er måske faldet bort i teksten.

187. Dvs. biskop Alexander, Athanasios' forgænger som biskop i Alexandria.

188. Ifølge Lefort (1955), står der H€l, "hus" i håndskriftet (AS). Faktisk læser håndskriftet пєı, "kys", men det må være en fejl, således at Leforts læsning må fastholdes, men som tekstrettelse. 
for enhver plet, for tvesindetheden og striden og hovmodet hos de små børn. Lad os være tilfredse med skriften alene, indblæst af Gud [jf. 2 Tim 3,16], til at belære os. Denne (skrift), hvis bøger vi har forkyndt i de ord, der var ovenfor: Hvilke de er, og hvor mange de er i deres antal. For på denne måde holder vi nu fest, ligesom det sømmer sig, hverken med gammel surdej, heller ikke med ondskabs og sletheds surdej, men tværtimod med renheds og sandheds surdeje [jf. 1 Kor 5,8].

33 Den hellige fastetid vil vi begynde den femogtyvende i måneden Emšir ${ }^{189}$ men den frelsende påskes store uge på den sidste dag i måneden Parmhotp. ${ }^{190} \mathrm{Og}$ vi vil afslutte de hellige fastedage på den femte i måneden Parmoute, ${ }^{191}$ og efter den ${ }^{192}$ vil vi også holde fest i de andre syv uger af den hellige pinse, idet vi mindes de fattige og sender dele (af nadverbrødet) ${ }^{193}$ til hinanden og dem, som er i nød, i overensstemmelse med Ezras ord, ${ }^{194}$ idet vi i det hele taget udfører alting og i overensstemmelse med Paulus' befaling [jf. 1 Kor 10,31] ærer Gud ved Jesus Kristus vor Herre, han gennem hvem æren og magten er sammen med Helligånden i evighedernes evigheder. Amen.

Hils hverandre med et helligt kys! Alle brødrene sammen med mig hilser jer! ${ }^{195}$

34 Men jeg oplyser jer også, at da den salige Lampon, biskop i Darnis, gik til hvile, blev [ ] udpeget [196

189. Dvs. den 29. februar.

190. Således AS; AT: "den".

191. Dvs. den 31. marts; påskedag fulgte så den 1. april 367.

192. Således Lefort (1955); i håndskriftet (AS) er der sekundære rettelser.

193. Den sahidiske tekst bruger det græske låneord $\mu \varepsilon \rho i ́ s ; ~ L a m p e ~ 843 b$ nævner betydningerne "portion"; "portion (of eucharistic bread)".

194. Jf. 2 Ezra 18,10 = Neh 8,10. Se ovenfor note 94 om 2 Ezra i LXX.

195. Jf. Rom 16,16; Fil 4,21 etc.

196. I tre andre af Athanasios' påskebreve, samt i påskebreve fra nogle af hans efterfølgere, findes der efter de afsluttende hilsener lignende underretninger om afdøde egyptiske biskopper og deres efterfølgere, jf. Allen (2014), 7. Lampon kender vi ikke fra andre kilder, men Darnis var ifølge Schmidt (1902), 333 sæde for metropolitanbiskoppen i den romerske provins Libya inferior. Den sahidiske oversætter har

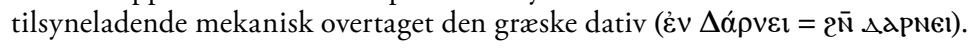

